\title{
PERTUMBUHAN INKLUSIF : FENOMENA PERTUMBUHAN INKLUSIF DI KAWASAN INDONESIA BAGIAN BARAT DAN INDONESIA BAGIAN TIMUR
}

\author{
Dyah Hapsari Amalina $S^{1}$, M.Parulian Hutagaol ${ }^{2}$, Alla Asmara ${ }^{2}$ \\ ${ }^{1}$ Staf Kementerian Perdagangan dan Mahasiswa Magister Program Studi Ilmu \\ Ekonomi, FEM IPB \\ ${ }^{2}$ Staf Pengajar FEM IPB
}

Artikel diterima Maret 2013

Artikel disetujui untuk dipublikasikan Desember 2013

\begin{abstract}
The growth of the middle class in Indonesia that occurred during the last ten years allegedly raised by the economic growth that is likely to increase in the same period. An economic theory which states that inclusive growth is growth that is able to bring the middle class makes economists focus on inclusive growth and the middle class itself. But in fact, the middle class in Indonesia is dominated by the lower middle class whose features are similar to the poor. These issues indicate a gap in the economy. In addition, to talk about the gap, there is no doubt that this issue has long been a discussion in Indonesia, especially the gap between western Indonesia and eastern Indonesia. Therefore this study was conducted to analyze whether it is true that inclusive growth has occurred in Indonesia and how the phenomena that occur in the western part of Indonesia and eastern Indonesia. Based on the data from 33 provinces in Indonesia over a period of 5 years, ie from 2008 to 2012, this study of the Measured inclusive growth by adopting the concept formulated by Klasen (2010) on-Poverty Equivalent Growth Rate (PEGR). This study of the processing of data performed using Excel and SPSS software. The results found that economic growth in Indonesia in 20082012 has not been inclusive in reducing poverty, lowering inequality and increase employment. The results also show that inclusive growth is not a consistent phenomenon in Indonesia. The phenomenon of inclusive growth in reducing poverty, lowering inequality, and increasing employment are more prevalent in Western Indonesia (IBB).
\end{abstract}

Key words : inclusive, growth, middle class, panel data, excel

\section{PENDAHULUAN \\ Latar Belakang dan Permasalahan}

Pertumbuhan ekonomi yang cenderung meningkat selama beberapa tahun terakhir telah menghasilkan perubahan yang struktural dalam komposisi pendapatan penduduk Indonesia. Perubahan struktural ini ditandai dengan menurunnya jumlah penduduk miskin dan nyaris miskin yang disertai dengan ekspansi kelas menengah secara signifikan dalam 10 tahun terakhir. Berdasarkan proporsinya terhadap total populasi, kelas menengah di Indonesia meningkat dari 25 persen pada tahun 1999 menjadi 43 persen 
pada tahun 2009 (SUSENAS, 1999 dan 2009). Sedangkan perhitungan yang dilakukan World Bank menunjukkan bahwa dalam tujuh tahun kelas menengah di Indonesia bertambah 50 juta orang.

Kategori kelas menengah versi World Bank adalah mereka yang membelanjakan uangnya 2 dollar AS (sekitar Rp 18.000) sampai 20 dollar AS (sekitar Rp 180.000) per hari. Berdasarkan klasifikasi tersebut, dapat dilihat bahwa pada tahun 2003 sebesar 37,7 persen atau 81 juta penduduk
Indonesia tergolong kelas menengah, dan pada tahun 2010, proporsi kelompok kelas menengah sudah melebihi separuh penduduk Indonesia (56,6 persen atau 131 juta penduduk). Artinya saat ini ada sekitar 134 juta warga kelas menengah di Indonesia. Ekspansi kelas menengah ini terjadi pada kelompok bagian terbawah dan menengah dari kelompok menengah (low middle and mid middle classes). Ekspansi kelas menengah di Indonesia dapat dilihat pada gambar 1 .

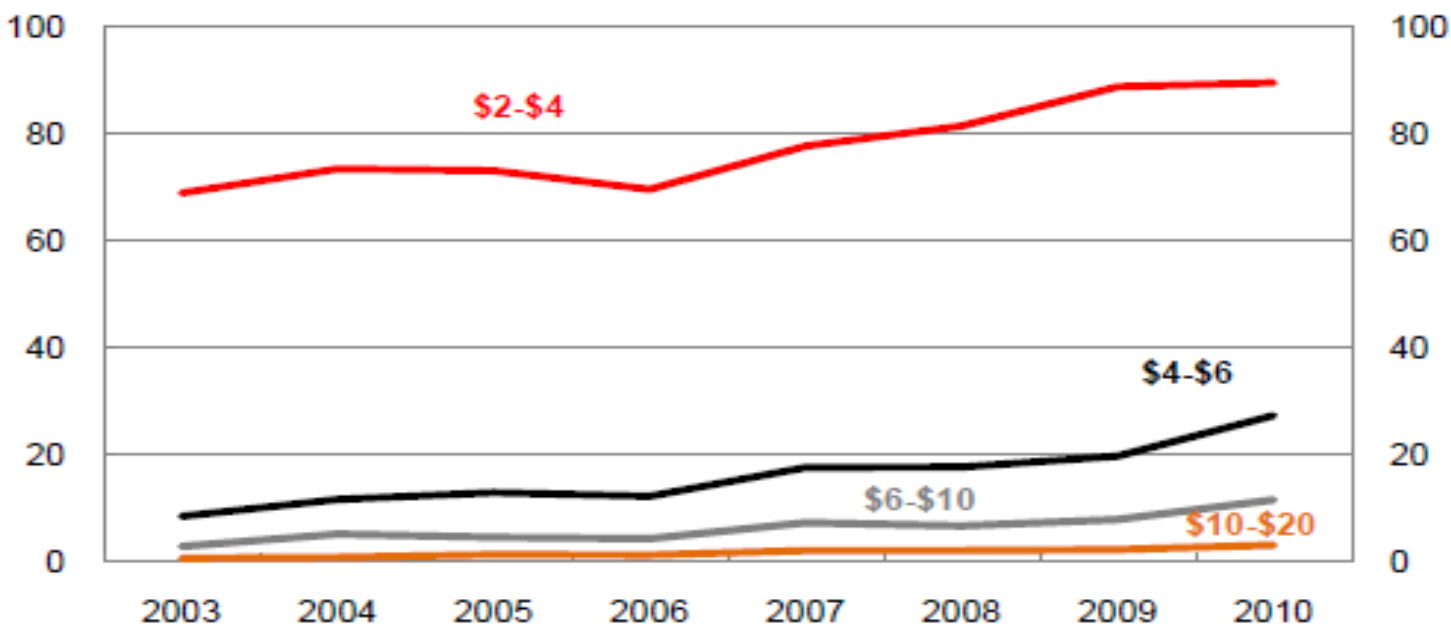

Sumber : The World Bank, Indonesia Economic Quarterly (2008 Again, March 2011)

Gambar 1 Ekspansi Pendapatan di Indonesia

Dari gambar 1 dapat dilihat bahwa kelas menengah bawah, yaitu dengan pendapatan \$2-\$4 per kapita, mendominasi ekspansi dalam periode 2006 hingga 2009. Sedangkan pada tahun 2009 dan 2010, ekspansi terbesar terjadi pada kelompok pendapatan per kapita \$4-\$6 (mid middle class). Hal ini berarti ekspansi kelas menengah di Indonesia terjadi sebagian besar pada kelompok bagian terbawah dan menengah dari kelompok menengah (low middle and mid middle class).

Kelas menengah yang diduga dimunculkan oleh pertumbuhan ekonomi mendorong ekonom untuk semakin fokus terhadap pertumbuhan ekonomi. Besarnya manfaat yang dapat diberikan oleh adanya kelas menengah semakin mengukuhkan perhatian ekonom untuk terus fokus pada pertumbuhan ekonomi sebagai faktor utama yang memunculkan kelas menengah. Birdsall (2007) berpendapat bahwa pertumbuhan inklusif (inclusive growth), merupakan pertumbuhan yang kondusif untuk meningkatkan ukuran dan kemampuan ekonomi kelasmenengah. Dengan demikian, dapat dikatakan bahwa pertumbuhan ekonomi di Indonesia yang diiringi dengan pertumbuhan kelas menengah secara 
signifikan menunjukkan bahwa pertumbuhan tersebut merupakan pertumbuhan yang inklusif.

Berbagai konsep yang ditawarkan untuk merumuskan pertumbuhan inklusif memiliki pandangan masingmasing mengenai bagaimana seharusnya pertumbuhan dapat bekerja dalam perekonomian. Faktor-faktor seperti ketimpangan, kemiskinan, masalah sektoral dan tenaga kerja seringkali disebutkan dalam uraian mengenai berbagai konsep pertumbuhan inklusif. Pertumbuhan inklusif dapat dikatakan sebagai ukuran apakah pertumbuhan ekonomi suatu negara merupakan pertumbuhan yang berkualitas. Pertumbuhan ekonomi disebut inklusif apabila pertumbuhan tersebut mampu menurunkan kemiskinan, menurunkan ketimpangan distribusi pendapatan, dan menyerap lebih banyak tenaga kerja.

Meskipun ada indikasi bahwa pertumbuhan yang inklusif telah terjadi di Indonesia dengan adanya kebangkitan kelas menengah, tetapi kelas menengah tersebut masih didominasi oleh kelompok menengah bawah. Hal itu menunjukkan masih adanya kesenjangan dalam pertumbuhan kelas menengah. Jika kesenjangan kelas menengah menunjukkan adanya kesenjangan ekonomi, maka hal itu akan menciptakan kesenjangan ekonomi yang semakin parah. Idealnya, pertumbuhan kelas menengah dapat lebih seimbang khususnya pada kelompok menengah dari kelas menengah dan hal ini dapat diupayakan dengan menciptakan pertumbuhan yang inklusif.

Persoalan kesenjangan yang terjadi pada kelas menengah tidak lepas dari adanya masalah kesenjangan dalam pembangunan dan pemerataan hasilhasil pembangunan. Pembangunan di daerah-daerah yang bersifat pembangunan regional, pembangunan wilayah atas pembangunan kawasan, dalam skala apapun, adalah bagian terpadu dari pembangunan nasional yang ditujukan untuk meningkatkan kemampuan dan kesejahteraan masyarakat secara merata. Dengan begitu luasnya wilayah Indonesia yang terdiri dari pulau dan kepulauan, persoalan kurangnya pemerataan pembangunan telah lama muncul terutama antara wilayah Indonesia Bagian Barat (IBB) dengan Indonesia Bagian Timur (IBT). Pembangunan yang didominasi pada provinsi-provinsi yang termasuk dalam IBB, yaitu seluruh provinsi di Pulau Jawa dan Sumatera, membuat kawasan IBT relatif masih jauh tertinggal baik dalam hal prasarana fisik, sosial, sumber daya (modal maupun manusia), maupun kelembagaan. Data BPS menunjukkan bahwa 82 persen PDB Indonesia dikuasai oleh provinsi-provinsi di IBB, sedangkan sisanya terdistribusi di seluruh provinsi pada IBT (BPS, 20082012).

Walaupun bukan isu baru, tema pertumbuhan inklusif hingga saat ini semakin menarik perhatian dan dianggap penting. Berbagai indikator yang mencirikan pertumbuhan inklusif terus dikembangkan, termasuk bagaimana metode mengukur pertumbuhan inklusif. Isu pertumbuhan inklusif semakin menarik dengan munculnya kelas menengah yang mengindikasikan bahwa pertumbuhan ekonomi yang terjadi telah inklusif. Namun pada kenyataannya, kelas menengah yang muncul di Indonesia menunjukkan adanya kesenjangan ekonomi. Persoalan kesenjangan tentunya berlawanan dengan konsep pertumbuhan inklusif dimana pertumbuhan mampu menurunkan ketimpangan. Selain itu, persoalan 
kesenjangan antara wilayah IBB dan IBT yang telah lama dibahas di Indonesia sejauh ini masih luput dari pembahasan kelas menengah maupun pertumbuhan inklusif yang dilakukan oleh World Bank dan ADB.

Berdasarkan uraian latar belakang tersebut, penelitian ini dilakukan untuk menjawab permasalahan berikut :

1. Apakah pertumbuhan ekonomi di Indonesia telah inklusif?

2. Apakah pertumbuhan inklusif merupakan fenomena yang konsisten di Indonesia?

3. Bagaimana fenomena pertumbuhan inklusif di wilayah Indonesia Bagian Barat (IBB) dan Indonesia Bagian Timur (IBT) ?

\section{TINJAUAN PUSTAKA}

\section{Definisi Pertumbuhan Inklusif}

Pertumbuhan merupakan syarat penting bagi terciptanya pertumbuhan inklusif. Klasen (ADB, 2010) menyatakan bahwa penting untuk menentukan episode ekonomi seperti apa yang memiliki karakteristik sebagai pertumbuhan yang inklusif. Ada dua kemungkinan untuk hal tersebut, yang pertama melihat melalui proses. Pertumbuhan ekonomi yang inklusif adalah pertumbuhan yang meluas antar sektor atau intensif terhadap tenaga kerja. Dengan begitu pertumbuhan inklusif dapat dikatakan sebagai pertumbuhan yang melibatkan partisipasi semua pihak tanpa diskriminasi dan mampu melibatkan seluruh sektor ekonomi. Fokus kedua yaitu pada hasil dari proses pertumbuhan. Dalam hal ini, konsep pertumbuhan inklusif berkaitan erat dengan konsep pertumbuhan yang pro poor. Dengan kata lain, berdasarkan hasil yang dicapainya, pertumbuhan inklusif adalah pertumbuhan yang mampu menurunkan kelompok yang "tidak diuntungkan" dalam perekonomian. Berdasarkan kedua fokus tersebut, pertumbuhan inklusif dapat didefinisikan sebagai pertumbuhan yang tidak mendiskriminasikan dan mampu menjamin pemerataan akses pertumbuhan sekaligus sebagai pertumbuhan yang mampu menurunkan kelompok yang tidak memperoleh keuntungan dari pertumbuhan (mengurangi disparitas antar kelompok).

Studi literatur yang dilakukan Suryanarayana (2007) mengenai konsep pertumbuhan inklusif memberikan beberapa interpretasi sebagai berikut :

- Pertumbuhan inklusif menurut Bank Dunia adalah pertumbuhan yang fokus pada perluasan skala ekonomi, memperluas akses terhadap aset perekonomian dan berhasil memperluas pasar serta menciptakan pemerataan peluang untuk generasi selanjutnya.

- Syarat penting untuk terciptanya pertumbuhan inklusif adalah bahwa disparitas pendapatan antara pekerja di sektor pertanian dan non-pertanian seharusnya tidak terlalu besar (Sen 2007)

- Besley et al (2007) menggunakan elastisitas pertumbuhan terhadap kemiskinan untuk mengukur inklusifitas proses pertumbuhan terhadap kemiskinan

- UNDP memberikan definisi mengenai pertumbuhan inklusif berdasarkan sisi produksi dan pendapatan GDP (Gross Domestic Product), yaitu proses dan hasil pertumbuhan dimana semua pihak dapat berpartisipasi dan memperoleh manfaat yang sama dari pertumbuhan tersebut. Dengan demikian pertumbuhan inklusif merepresentasikan pemerataan. 
Konsep lain mengenai pertumbuhan inklusif dinyatakan dalam analisis yang dilakukan oleh Rusastra (2011). Rusastra menyatakan bahwa pembangunan dan pertumbuhan inklusif secara nasional membutuhkan beberapa upaya, yaitu: (1) stabilisasi indikator makroekonomi, didukung oleh keberpihakan kebijakan fiskal dan sistem insentif untuk pembangunan pertanian; (2) peningkatan kapasitas produksi, didukung oleh pengembangan infrastruktur dan pelestarian sumber daya alam dalam perspektif menjaga keberlanjutan pertumbuhan ekonomi jangka panjang; (3) sinergi dan integrasi program pemberdayaan kelompok miskin, pembangunan inklusif perdesaan, dan pertumbuhan inklusif di tingkat nasional; dan (4) peningkatan kapasitas dan akses penduduk miskin, proteksi penguasaan aset produktif, dan percepatan peningkatan pendapatan. Berdasarkan uraian tersebut, maka pertumbuhan inklusif dapat dikatakan sebagai pertumbuhan yang mampu mensinergikan pertumbuhan ekonomi, peningkatan kesempatan kerja, dan pengentasan kemiskinan.

Pengertian pertumbuhan inklusif yang berhubungan dekat dengan konsep kemiskinan didukung oleh Habito (2009). Menurut kesimpulannya, pertumbuhan inklusif didefinisikan sebagai pertumbuhan GDP yang dapat menurunkan kemiskinan. Habito juga menjelaskan bahwa struktur perekonomian dan komposisi sektoral dalam pertumbuhan ekonomi telah diyakini sebagai faktor penting untuk mencapai pertumbuhan inklusif, dengan pernyataan umum bahwa pertumbuhan yang lebih kuat pada struktur pertanian akan mempercepat penurunan kemiskinan. Penekanan pada sektor pertanian ini wajar bila mengingat bahwa peran sektor pertanian terutama dalam penyerapan tenaga kerja di negara berkembang sangat besar. Selain fokus akan kondisi sektor perekonomian, Habito memandang investasi pada fasilitas publik seperti kesehatan, pendidikan dan perumahan sangat penting untuk mencapai pertumbuhan inklusif.

Min Tang (2008) memberikan perhatian terhadap persoalan kemiskinan dalam kaitannya dengan pertumbuhan inklusif dengan berangkat dari persoalan distribusi pendapatan. Ia mengamati bahwa selama beberapa dekade, banyak negara berkembang yang memiliki pertumbuhan ekonomi yang luar biasa. Sementara itu, distribusi pendapatan semakin memburuk dengan derajat yang berbeda-beda antar negara. Beragam ukuran dan elemen dinyatakan turut memengaruhi apakah pertumbuhan dapat dikatakan inklusif. Ukuran yang paling penting adalah apakah pertumbuhan memiliki dampak terhadap peningkatan kesejahteraan orang miskin. Orang miskin, yang merupakan pihak dengan posisi paling tidak menguntungkan dalam pembangunan, memiliki kesulitan untuk memperoleh manfaat dari hasil pembangunan. Karena itu, meningkatkan kualitas hidup masyarakat miskin merupakan prioritas utama dalam agenda pertumbuhan ekonomi, tetapi terbukti sangat sulit untuk dicapai. Pertumbuhan inklusif sangat sering disamakan dengan inklusifitas pro poor, dengan demikian pertumbuhan yang tidak pro poor sudah pasti tidak inklusif (Kakwani, Khander, dan Son, 2004; dalam Min Tang, 2008).

Persoalan ketimpangan tidak luput menjadi perhatian dalam pembahasan mengenai pertumbuhan inklusif. Ali (2007) menyatakan bahwa pertumbuhan inklusif yang fokus pada percepatan perluasan kesempatan dan akses 
terhadap sumberdaya ekonomi bagi seluruh pelaku ekonomi, termasuk kelompok yang kurang diuntungkan, adalah syarat penting tetapi belum cukup untuk menurunkan ketimpangan pendapatan. Ketimpangan telah meningkat, tetapi hal ini bukan berarti bahwa orang kaya semakin kaya sedangkan orang miskin semakin miskin. Melainkan kekayaan orang kaya meningkat jauh lebih cepat dari pada orang miskin. Dengan melihat pada persoalan ketimpangan yang terjadi, Ali memberi kesimpulan bahwa faktor kunci yang bertanggungjawab atas peningkatan ketimpangan terlihat beragam dalam pertumbuhan. Tiga dimensi dalam perbedaan pertumbuhan terutama berkenaan dengan perbedaan pengukuran ketimpangan di berbagai bagian daerah. Yang pertama, pertumbuhan telah berbeda antar daerah di suatu negara (misalnya antar propinsi). Kedua, pertumbuhan berbeda antar kota dan desa. Dan yang terakhir, pertumbuhan berbeda antar rumah tangga, sehingga pendapatan masyarakat kelas atas tumbuh lebih cepat dari pada masyarakat kelas menengah atau dibawahnya.

Faktor-faktor seperti ketimpangan, kemiskinan, masalah sektoral dan tenaga kerja seringkali disebutkan dalam uraian mengenai berbagai konsep pertumbuhan inklusif. Ianchovichina dan Lundstrom (2009) memberikan pendapat yang sedikit berbeda, dimana keduanya memperhatikan kembali persoalan ukuran pertumbuhan. Ianchovichina dan Lundstrom menyatakan bahwa pertumbuhan inklusif berkaitan dengan memperbesar ukuran perekonomian dan bukan hanya fokus pada masalah distribusi sumber daya.

Pertumbuhan Inklusif seringkali dikaitkan pula dengan pertumbuhan berkelanjutan merupakan konsep sederhana namun kompleks, sehingga pengertian keberlanjutanpun sangat multidimensi dan multiinterpretasi. Menurut Heal (1998), konsep keberlanjutan ini paling tidak mengandung dua dimensi: Pertama adalah dimensi waktu karena keberlanjutan tidak lain menyangkut apa yang akan terjadi di masa yang akan datang. Kedua adalah dimensi interaksi antara sistem ekonomi dan sumber daya alam dan lingkungan. Karena adanya multidimensi dan multi-interpretasi ini, maka para ahli sepakat untuk sementara mengadopsi pengertian yang telah disepakati oleh komisi Brundtland yang menyatakan bahwa "Pembangunan berkelanjutan adalah pembangunan yang memenuhi kebutuhan generasi saat ini tanpa mengurangi kemampuan generasi mendatang untuk memenuhi kebutuhan mereka." (ADB, 1990). Dengan melihat komponen antar waktu yang menjadi indikator pertumbuhan berkelanjutan, maka dapat dikatakan bahwa pertumbuhan yang berkelanjutan adalah pertumbuhan inklusif namun pertumbuhan inklusif belum tentu berkelanjutan.

Berbagai konsep yang ditawarkan untuk merumuskan pertumbuhan inklusif memiliki pandangan masingmasing mengenai bagaimana seharusnya pertumbuhan dapat bekerja dalam perekonomian. Pertumbuhan inklusif dapat dikatakan sebagai ukuran apakah pertumbuhan ekonomi suatu negara merupakan pertumbuhan yang berkualitas. Definisi pertumbuhan inklusif dalam penelitian ini merupakan gabungan dari beragam konsep yang telah diuraikan sebelumnya. Dengan demikian, pertumbuhan ekonomi disebut inklusif apabila pertumbuhan tersebut mampu menurunkan kemiskinan, menurunkan ketimpangan distribusi pendapatan, dan menyerap lebih banyak tenaga kerja. 


\section{Pengukuran Pertumbuhan Inklusif}

Dengan

mendefinisikan

pertumbuhan inklusif sebagai

pertumbuhan yang mampu

meningkatkan fungsi peluang sosial (social opportunity function), Ali dan Son (2007) telah merumuskan salah satu pendekatan untuk mengukur pertumbuhan inklusif. Dalam konteks ini, pertumbuhan inklusif tergantung pada dua faktor : (i) rata-rata kesempatan yang tersedia untuk penduduk, dan (ii) bagaimana peluang dibagi di antara populasi.

Menurut Ali dan Son (2007), fungsi peluang sosial memberikan bobot yang lebih besar kepada peluang yang dinikmati oleh orang miskin: semakin miskin, maka bobotnya semakin besar. Skema pembobotan akan memastikan bahwa peluang yang diciptakan untuk orang miskin lebih penting daripada yang dibuat untuk mereka yang tidak miskin, yaitu jika kesempatan yang dinikmati oleh seseorang dipindahkan kepada orang miskin dalam masyarakat, maka peluang sosial harus meningkat, sehingga membuat pertumbuhan menjadi lebih inklusif.

Pertumbuhan dikatakan inklusif jika peluang sosial dapat tersebar pada seluruh populasi. Bagaimana peluang dapat tersebar dalam masyarakat menurut Ali dan Son (2007) dapat digambarkan dalam kurva yang disebut sebagai kurva peluang : semakin tinggi kurva, semakin besar fungsi peluang sosial. Dengan demikian pertumbuhan akan inklusif jika kurva peluang bergeser ke atas pada semua titik. Jika kurva peluang secara keseluruhan bergeser ke atas, maka artinya setiap orang dalam masyarakat, termasuk orang miskin, menikmati peningkatan peluang dan karenanya bisa disebut suatu proses pertumbuhan yang inklusif. Kemiringan pada kurva peluang sosial menunjukkan bagaimana peluang didistribusikan dalam masyarakat. Jika kurva peluang memiliki kemiringan negatif, maka dapat dikatakan bahwa kesempatan yang tersedia untuk orang miskin lebih daripada yang tersedia untuk yang tidak miskin (yaitu, peluang didistribusikan secara merata). Demikian pula, jika kurva memilki kemiringan positif, maka artinya peluang didistribusikan secara tidak adil (antipoor).

Salah satu bentuk sederhana fungsi peluang sosial yang diajukan Ali dan Son (2007) dapat diperoleh dengan menghitung indeks dari daerah di bawah kurva peluang seperti yang dinyatakan pada persamaan berikut ini :

$$
\bar{y}^{*}=\int_{0}^{1} \bar{y}_{p} d p
$$

Persamaan 1 dinamakan dengan index peluang (OI, Opportunity Index). Semakin besar $\bar{y}^{*}$, maka akan semakin besar peluang yang tersedia untuk populasi. Dengan demikian tujuan utama model yang dibangun disini adalah untuk memaksimumkan nilai $\bar{y}^{*}$. Jika setiap orang dalam populasi menikmati kesempatan yang sama, maka dapat ditunjukkan bahwa $\bar{y}^{*}$ akan sama dengan $\bar{y}$. Dengan demikian, penyimpangan $\bar{y}^{*}$ dari $\bar{y}$ memberikan indikasi tentang bagaimana peluang tersebar di seluruh populasi. Jika $\bar{y}^{*}$ lebih besar dari $\bar{y}$, maka peluang terdistribusi secara merata (pro-poor). Demikian pula, jika $\bar{y}^{*}$ kurang dari $\bar{y}$, maka peluang yang tidak adil didistribusikan (antipoor). Berdasarkan uraian tersebut, maka indeks pemerataan peluang (EIO, Equity Index of Opportunity) dirumuskan sebagai berikut •

$$
\varphi=\frac{\bar{y}^{*}}{\bar{y}}
$$


yang berarti bahwa peluang secara adil (tidak adil) didistribusikan jika $\varphi$ adalah lebih besar (kurang) dari 1. Dari (2), ditentukan bahwa :

$$
\bar{y}^{*}=\varphi \bar{y}
$$

yang .............kkan bahwa OI merupakan produk EIO dan tingkat rata-rata peluang yang tersedia bagi populasi. Untuk mencapai pertumbuhan yang inklusif, maka $\bar{y}^{*}$ harus ditingkatkan, hal ini dapat dicapai dengan: (i) meningkatkan tingkat peluang $\bar{y}$, (ii) meningkatkan indeks ekuitas peluang $\varphi$, atau (iii) meningkatkan keduanya. Untuk memahami dinamika pertumbuhan inklusif, maka Ali dan Son (2007) mengajukan rumusan berikut :

$$
d \bar{y}^{*}=\varphi d \bar{y}+\bar{y} d \varphi
$$

Dimana $\mathrm{dy}^{*}$ mengukur perubahan derajat inklusifitas pertumbuhan. Pertumbuhan menjadi lebih inklusif ketika dy ${ }^{*}>0$. Bagian pertama di sebelah kanan persamaan (4) adalah kontribusi yang diberikan oleh kenaikan rata-rata peluang sosial terhadap inklusifitas pertumbuhan ketika peluang relatif tidak berubah; bagian kedua dari persamaan menunjukkan kontribusi perubahan distribusi ketika peluang rata-rata tidak berubah.

Selain dengan fungsi peluang sosial yang diajukan Ali dan Son, pendekatan lain dapat digunakan untuk menganalisis dan mengukur pertumbuhan inklusif. Salah satunya adalah yang dilakukan oleh Ianchovichina dan Lundstrom (2009), yang mengadopsi kerangka Hausmann, Rodrik, and Velasco (HRV) (2005).

Kerangka HRV hanyalah satu di antara banyak pendekatan untuk analisis pertumbuhan yang inklusif. Hal ini sangat relevan dalam kasus di mana tingkat pendapatan rendah, pertumbuhan lambat dan investasi rendah. Dengan latar belakang demikian, kerangka HRV merupakan kerangka kerja yang tepat untuk mempelajari isu-isu pertumbuhan inklusif karena pertumbuhan adalah pendorong utama pengurangan kemiskinan. Menurut pendekatan ini, jika seseorang mendefinisikan pendapatan dari setiap individu i sebagai:

$$
y_{i} \equiv w_{1} E_{1} \omega_{i 1}+\ldots+w_{j} E_{j} \omega_{i j}
$$

dimana $w_{j}$ adalah harga, $E_{j}$ adalah sumbangan dari masing-masing faktor $\mathrm{j}$ perekonomian, dan $\omega_{\mathrm{ij}}$ - bagian dari faktor $\mathrm{j}$ yang dimiliki oleh individu $\mathrm{i}$. Kemudian, dengan membagi setiap sisi dengan pendapatan total dan menjumlahkan seluruh kelompok tertentu individu, misalnya kelompok miskin, diperoleh:

$$
\psi_{P} \equiv \lambda_{1} \omega_{P 1}+\ldots+\lambda_{j} \omega_{P j}
$$

dimana $\psi_{\mathrm{P}}$ adalah bagian dari pendapatan yang diterima oleh kelompok kepentingan, $\lambda_{\mathrm{j}}$ adalah bagian dari faktor i di total pendapatan, dan $\omega_{\mathrm{Pj}}$ adalah bagian dari faktor $\mathrm{j}$ yang dimiliki oleh kelompok. Identitas ini menunjukkan variabel yang memengaruhi bagian pendapatan dari kelompok yang menjadi fokus. Dalam pendekatan yang digunakan Ianchovichina dan Lundstrom (2009), Instrumen utama untuk pertumbuhan yang berkelanjutan dan inklusif yaitu pekerjaan yang produktif. Oleh karena itu, pertumbuhan yang inklusif tidak hanya tentang pertumbuhan lapangan kerja, tetapi juga tentang pertumbuhan produktivitas. Kemampuan individu untuk dapat dipekerjakan secara 
produktif tergantung pada peluang untuk memanfaatkan sepenuhnya sumber daya yang tersedia karena ekonomi berkembang dari waktu ke waktu.

Alternatif lain untuk mengukur pertumbuhan inklusif dirumuskan oleh Klasen (2010). Menurutnya, pendekatan yang sederhana untuk memeriksa pertumbuhan yang inklusif diperlukan. Dalam merumuskan metode pengukuran untuk pertumbuhan inklusif, Klasen mengadaptasi metode dari penelitian-penelitian pro-poor growth. Secara khusus, adaptasi dilakukan dari penelitian Kakwani dan Son (2008) mengenai konsep "povertyequivalent growth rate" yang mendefinisikan pertumbuhan inklusif sebagai pertumbuhan untuk kelompok kurang beruntung.

Manfaat pertumbuhan bisa dihitung dengan menggunakan metode PEGR yang merupakan salah satu metode yang digunakan untuk mengukur manfaat pertumbuhan ekonomi bagi penduduk miskin. Dalam penghitungan PEGR sendiri, terdapat 2 metode, yaitu dengan menggunakan teknik analisis secara $e x$ ante dan post ante.

Metode penghitungan PEGR dengan menggunakan teknik analisis secara $e x$ ante diterapkan berdasarkan asumsi bahwa perubahan ketidakmerataan pendapatan hanya berlangsung dengan cara terjadi pergeseran secara proporsional dan konstan di semua titik pada kurva Lorenz. Padahal pergeseran kurva Lorenz dapat disebabkan banyak hal, sehingga metode penghitungan PEGR secara ex-ante ini tidak mungkin untuk dilakukan.

Metode penghitungan PEGR dengan menggunakan teknik analisis ex-post dilakukan untuk mengatasi permasalahan penghitungan secara $e x$ ante, yaitu dengan cara membandingkan keadaan kemiskinan, distribusi pendapatan (kurva Lorenz) dan rata-rata pendapatan penduduk pada awal periode dengan keadaan pada akhir periode. Misalkan ukuran kemiskinan merupakan fungsi dari garis kemiskinan $\mathrm{z}$, rata-rata pendapatan $\mu$, dan kurva Lorenz $L(p)$, yang dituliskan sebagai berikut:

$P=P(z, \mu, L(p))$

Jika ukuran kemiskinan yang digunakan adalah :

$$
P_{\alpha}=\frac{1}{n} \sum_{i=1}^{q}\left[\frac{z-y_{i}}{z}\right]^{\alpha}
$$

dimana $\alpha=0,1,2$ dan $y_{i}=$ pendapatan penduduk ke-i dan $\mathrm{q}=$ jumlah penduduk miskin. Maka perubahan persentase penduduk miskin pada periode 1 dan periode 2 dapat dituliskan sebagai berikut :

$$
P_{12}=P_{2}-P_{1}=\operatorname{Ln}\left[P\left(z, \mu_{2}, L_{2}(p)\right]-\operatorname{Ln}\left[P\left(z, \mu_{1}, L_{1}(p)\right)\right]\right.
$$

Nilai $P_{12}$ ini masih mengandung komponen pertumbuhan dan komponen distribusi.

Misalkan $\mu_{1}$ dan $\mu_{2}$ merupakan rata-rata pendapatan penduduk pada periode 1 dan periode 2, maka pertumbuhan pendapatan penduduk $(\hat{\gamma})$ dapat dirumuskan sebagai berikut:

$$
\hat{\gamma}=\operatorname{Ln}\left(\mu_{2}\right)-\operatorname{Ln}\left(\mu_{1}\right)
$$

Total elastisitas kemiskinan $(\delta)$ dapat didekomposisi menjadi elastisitas kemiskinan yang berkaitan dengan pertumbuhan $(\eta)$ dan elastisitas kemiskinan yang berkaitan dengan ketidakmerataan $(\zeta)$. Persamaan untuk total elastisitas $(\delta)$ sebagai berikut: 


$$
\begin{gathered}
\hat{\delta}=\left(\operatorname { L n } \left[P\left(z, \mu_{2}, \mathrm{~L}_{2}(\mathrm{p})\right]-\operatorname{Ln}\left[P \left(z, \mu_{1},\right.\right.\right.\right. \\
\left.\left.L_{1}(p)\right]\right) / \hat{\gamma}
\end{gathered}
$$

$$
\operatorname{dan} \hat{\delta}=\hat{\eta}+\hat{\zeta}
$$

dimana elastisitas kemiskinan terhadap pertumbuhan dirumuskan sebagai berikut :

$\hat{\eta}=$

$\frac{1}{2 \gamma}\left[\operatorname{Ln}\left(P\left(z, \mu_{2}, L_{1}(p)\right)-\operatorname{Ln}\left(P\left(z, \mu_{1}, L_{1}(p)\right)+\operatorname{Ln}\left(P\left(z, \mu_{2}, L_{2}(p)\right)-\operatorname{Ln}\left(P\left(z, \mu_{1}, L_{2}(p)\right)\right]\right.\right.\right.\right.$

dan elastisitas kemiskinan terhadap ketidakmerataan dirumuskan sebagai berikut :

$\hat{\zeta}=\frac{1}{2 y}\left[\operatorname{Ln}\left(P\left(z, \mu_{1}, L_{2}(p)\right)-\operatorname{Ln}\left(P\left(z_{2}, \mu_{1}, L_{1}(p)\right)+\operatorname{Ln}\left(P\left(z, \mu_{2}, L_{2}(p)\right)\right)-\operatorname{Ln}\left(P\left(z, \mu_{2}, L_{1}(p)\right)\right]\right.\right.\right.$

Berdasarkan rumusan (11) hingga rumusan (14) tersebut, maka nilai PEGR dapat dirumuskan sebagai berikut :

$$
P E G R=\hat{\gamma}^{*}=(\hat{\delta} / \hat{\eta}) \hat{\gamma}
$$

Nilai PEGR dapat dikelompokkan sebagai berikut:

1. Jika $\hat{\gamma}^{*}=\hat{\gamma}$ maka artinya pertumbuhan bersifat netral, setiap orang menerima manfaat yang sama secara proporsional dari pertumbuhan.

2. Jika $\hat{\gamma}^{*}>\hat{\gamma}$ berarti pertumbuhan bersifat pro poor growth, penduduk miskin lebih banyak menerima manfaat dari pertumbuhan.

3. Jika $0<\hat{\gamma}^{*}<\hat{\gamma}$ artinya pertumbuhan belum bersifat pro poor growth, manfaat pertumbuhan lebih banyak diterima penduduk tidak miskin (ketidakmerataan meningkat) tetapi masih terjadi pengurangan Kemiskinan.

4. Jika $\hat{\gamma}^{*}<0$ berarti pertumbuhan bersifat anti pro poor growth atau manfaat pertumbuhan yang dinikmati penduduk tidak miskin, kemiskinan meningkat.

Dengan mengadopsi uraian mengenai konsep PEGR, maka pertumbuhan inklusif dapat diukur dengan rumusan berikut :

$I G_{i j}=\frac{G_{i j}}{\overline{G_{J}}} * \bar{G}_{J}$

Dimana :

$\mathrm{IG}_{\mathrm{ij}}=$ Koefisien pertumbuhan inklusif

$\mathrm{G}_{\mathrm{ij}} \quad=$ Pertumbuhan kelompok i dalam kaitannya dengan indikator $\mathrm{j}$

$\mathrm{G}_{\mathrm{j}} \quad=$ Pertumbuhan indikator $\mathrm{j}$

Dalam hal ini i mengacu pada kelompok kurang beruntung tertentu dan $\mathrm{j}$ mengacu pada indikator yang bersangkutan (misalnya, pertumbuhan pendapatan atau ekspansi dalam pendidikan).

\section{METODE PENELITIAN}

\section{Jenis dan Sumber Data}

Untuk memberikan gambaran nasional mengenai pertumbuhan inklusif dan kelas menengah di Indonesia, data yang digunakan dalam penelitian ini seluruhnya merupakan data provinsi-provinsi di Indonesia selama 10 tahun yaitu tahun 2002 hingga 2012.

Penelitian ini menggunakan data sekunder yang seluruhnya dikumpulkan oleh BPS. Data yang digunakan untuk menghitung inklusifitas pertumbuhan adalah data pendapatan perkapita, jumlah penduduk miskin, koefisien gini, jumlah orang yang bekerja, angkatan kerja dan Pendapatan Domestik Bruto Atas Dasar Harga Konstan (PDRB ADHK). Dengan demikian, maka semua data yang mewakili variabel penelitian merupakan data sekunder yang diperoleh dari berbagai laporan BPS. 


\section{Metode Analisis}

Metode kuantitatif merupakan metode yang dipakai untuk menjawab permasalahan dalam penelitian ini. Pengolahan data dalam penelitian dilakukan dengan menggunakan software excel dan SPSS. Untuk mengetahui ukuran pertumbuhan inklusif, digunakan pengukuran yang dirumuskan oleh Klasen (2010), dimana rumus pertumbuhan inklusif diadopsi dari konsep Poverty-Equivalent Growth Rate (PEGR).

\section{Mengukur Pertumbuhan Inklusif}

Telah diuraikan sebelumnya bahwa terdapat beberapa pendekatan yang dapat digunakan untuk mengukur pertumbuhan inklusif. Untuk menjawab permasalahan, penelitian ini menggunakan pendekatan yang dirumuskan oleh Klasen (2010).

Definisi pertumbuhan inklusif yang digunakan dalam penelitian ini merupakan gabungan dari beberapa konsep. Pertumbuhan disebut inklusif apabila pertumbuhan tersebut mampu menurunkan kemiskinan, menurunkan ketimpangan distribusi pendapatan, dan menyerap lebih banyak tenaga kerja. Persamaan (16) akan digunakan dalam penelitian untuk mengukur inklusifitas pertumbuhan berdasarkan ketiga indikator tersebut. Sedangkan untuk menghitung elastisitas sebagai komponen yang terdapat pada setiap perhitungan koefisien inklusif, maka penelitian akan mengadopsi konsep PEGR yang digunakan untuk menurunkan persamaan (11).

Dengan menjabarkan i dari persamaan 16 sebagai kemiskinan (p), ketimpangan (in) dan tenaga kerja (em), dan $\mathrm{j}$ mengacu pada indikator pertumbuhan ekonomi (g), maka dengan mengadopsi persamaan tersebut, pertumbuhan inklusif dapat diukur dengan rumusan sebagai berikut :

$$
\begin{aligned}
& \text { 1. Pertumbuhan inklusif dalam } \\
& \text { menurunkan kemiskinan, } \\
& \text { koefisiennya adalah : } \\
& \mathbf{I G}_{\mathbf{p}}=\left(\mathbf{G}_{\mathbf{p g}} / \mathbf{G}_{\mathbf{p}}\right) \hat{\mathbf{G}}_{\mathbf{g}}
\end{aligned}
$$

Dimana :

$\mathrm{IG}_{\mathrm{p}}$ : koefisien pertumbuhan inklusif dalam menurunkan kemiskinan

$\mathrm{G}_{\mathrm{p}}$ : elastisistas kemiskinan terhadap pendapatan rata-rata

$\mathrm{G}_{\mathrm{pg}}$ : elastisitas kemiskinan terhadap pertumbuhan ekonomi

$\hat{\mathrm{G}}_{\mathrm{g}}$ : pertumbuhan ekonomi

$\mathrm{IG}_{\mathrm{p}}$ menyatakan inklusifitas pertumbuhan dalam menurunkan kemiskinan, sehingga pertumbuhan dinyatakan inklusif apabila nilai $\mathrm{IG}_{\mathrm{p}}>$ $\hat{\mathrm{G}}_{\mathrm{g}}$.

Cara yang sama dalam konsep PEGR digunakan untuk menghitung elastisitas. Dengan mendefinisikan kemiskinan (P) sebagai fungsi dari jumlah penduduk miskin (z) dan pendapatan rata-rata penduduk $(x)$ yang dituliskan sebagai berikut :

$$
\mathbf{P}=\mathbf{P}(\mathbf{z}, \boldsymbol{x})
$$

Maka perubahan persentase jumlah penduduk miskin pada periode 1 dan periode 2 dapat dihitung sebagai :

$\mathbf{P}_{12}=\mathbf{P}_{2}-\mathbf{P}_{1}=\operatorname{Ln}\left[\mathbf{P}\left(\mathbf{z}_{2}, x_{2}\right)\right]-$ $\operatorname{Ln}\left[\mathbf{P}\left(z_{1}, x_{1}\right)\right]$

Sedangkan perubahan persentase pendapatan rata-rata penduduk dapat dihitung sebagai :

$$
\Psi=\operatorname{Ln}\left(x_{2}\right)-\operatorname{Ln}\left(x_{1}\right)
$$

Dengan demikian elastisitas kemiskinan terhadap pendapatan rata-rata $\left(\mathrm{G}_{\mathrm{p}}\right)$ dapat dihitung sebagai :

$\mathbf{G}_{\mathbf{p}}=\mathbf{P}_{12} / \Psi$

Pertumbuhan ekonomi $\left(\hat{\mathrm{G}}_{\mathrm{g}}\right)$ dihitung sebagai perubahan Produk Domestik Regional Bruto (PDRB) pada periode, sehingga pertumbuhan 
ekonomi dapat dituliskan sebagai berikut :

\section{$\hat{\mathbf{G}}_{\mathrm{g}}=\operatorname{Ln}\left(\mathrm{PDRB}_{2}\right)-\operatorname{Ln}\left(\mathrm{PDRB}_{1}\right)$}

Dengan demikian, elastisitas kemiskinan terhadap pertumbuhan ekonomi $\left(\mathrm{G}_{\mathrm{pg}}\right)$ dapat dihitung sebagai :

$\mathbf{G}_{\mathbf{p g}}=\mathbf{P}_{12} / \hat{\mathbf{G}}_{\mathrm{g}}$

2. Pertumbuhan inklusif dalam menurunkan ketimpangan, koefisiennya adalah :

$\mathbf{I G}_{\text {in }}=\left(\mathbf{G}_{\text {in.g }} / \mathbf{G}_{\text {in }}\right) \hat{\mathbf{G}}_{\mathrm{g}}$

Dimana :

$\mathrm{IG}_{\text {in }}$ : koefisien pertumbuhan inklusif dalam menurunkan ketimpangan

$\mathrm{G}_{\text {in }}$ : elastisistas ketimpangan terhadap pendapatan rata-rata

$\mathrm{G}_{\text {in.g }}$ : elastisitas ketimpangan terhadap pertumbuhan ekonomi

$\hat{\mathrm{G}}_{\mathrm{g}}$ : pertumbuhan ekonomi

$\mathrm{IG}_{\text {in }}$ menyatakan inklusifitas pertumbuhan dalam menurunkan ketimpangan, sehingga pertumbuhan dinyatakan inklusif apabila nilai $\mathrm{IG}_{\text {in }}>$ $\hat{\mathrm{G}}_{\mathrm{g}}$.

Dengan mendefinisikan ketimpangan (In) sebagai fungsi dari indeks gini (GINI) dan pendapatan ratarata penduduk $(x)$, yang dituliskan sebagai berikut :

In $=$ In (GINI, $x)$

Maka perubahan ketimpangan pada periode 1 dan periode 2 dapat dihitung sebagai :

$$
\begin{aligned}
& \operatorname{In}_{12}=\operatorname{In}_{2}-\operatorname{In}_{1}=\operatorname{Ln}\left[\operatorname { I n } \left(G_{I N I},\right.\right. \\
& \left.x_{2}\right)-\operatorname{Ln}\left[\operatorname{In}\left(G_{N} I_{1}\right)\right]
\end{aligned}
$$

Dengan menghitung perubahan persentase pendapatan rata-rata dari persamaan (19) maka elastisitas ketimpangan terhadap pendapatan ratarata $\left(\mathrm{G}_{\text {in }}\right)$ dapat dihitung sebagai :

$\mathbf{G}_{\text {in }}=\mathbf{I n}_{12} / \boldsymbol{\Psi}$

Sedangkan dari persamaan (21) yang menghitung pertumbuhan ekonomi, elastisitas ketimpangan terhadap pertumbuhan ekonomi $\left(\mathrm{G}_{\mathrm{in.g}}\right)$ dapat dihitung sebagai :

$$
\mathbf{G}_{\text {in.g }}=\mathbf{I n}_{12} / \hat{\mathbf{G}}_{\mathrm{g}}
$$

3. Pertumbuhan inklusif dalam meningkatkan penyerapan tenaga kerja, koefisiennya adalah :

$$
\mathbf{I G}_{\mathrm{em}}=\left(\mathbf{G}_{\mathrm{em} . \mathrm{g}} / \mathbf{G}_{\mathrm{em}}\right) \hat{\mathbf{G}}_{\mathrm{eg}}
$$

Dimana :

$\mathrm{IG}_{\mathrm{em}}$ : koefisien pertumbuhan inklusif dalam menyerap tenaga kerja

$\mathrm{G}_{\mathrm{em}}$ : elastisistas penyerapan tenaga kerja

$\mathrm{G}_{\mathrm{em} . \mathrm{g}}$ : elastisitas penyerapan tenaga kerja terhadap pertumbuhan ekonomi $\hat{\mathrm{G}}_{\mathrm{g}}$ : pertumbuhan ekonomi

$\mathrm{IG}_{\mathrm{em}}$ menyatakan inklusifitas pertumbuhan dalam menyerap tenaga kerja, sehingga pertumbuhan dinyatakan inklusif apabila nilai $\mathrm{IG}_{\mathrm{em}}>\hat{\mathrm{G}}_{\mathrm{eg}}$.

Dengan mendefinisikan penyerapan tenaga kerja (Em) sebagai fungsi dari jumlah orang yang bekerja (Worker) dan jumlah angkatan kerja (AK), yang dituliskan sebagai berikut :

Em = Em (Worker, AK)

Maka perubahan persentase penyerapan tenaga kerja pada periode 1 dan periode 2 dapat dihitung sebagai :

$$
\begin{aligned}
& \mathbf{E m}_{12}=\mathbf{E m}_{2}-\mathbf{E m}_{1}=\mathbf{L n}[\mathbf{E m} \\
& \left(\text { Worker }_{2}, \mathbf{A K}_{2}\right)-\mathbf{L n}[\mathbf{E m} \\
& \left.\left(\text { Worker }_{1}, \mathbf{A K}_{1}\right)\right]
\end{aligned}
$$

Sedangkan perubahan persentase angkatan kerja dapat dihitung sebagai : $A K^{*}=\operatorname{Ln}(\mathbf{A K} \mathbf{2})-\operatorname{Ln}\left(\mathbf{A K} \mathbf{K}_{1}\right)(30)$ 
Dengan demikian, elastisitas penyerapan tenaga kerja terhadap angkatan kerja $\left(\mathrm{G}_{\mathrm{em}}\right)$ dapat dihitung sebagai :

$$
\mathbf{G}_{\mathrm{em}}=\mathbf{E m}_{12} / \mathbf{A K} *
$$

Sedangkan dari persamaan (21) yang menghitung pertumbuhan ekonomi, elastisitas penyerapan tenaga kerja terhadap pertumbuhan ekonomi $\left(\mathrm{G}_{\mathrm{em} . \mathrm{g}}\right)$ dapat dihitung sebagai :

$\mathbf{G}_{\text {em.g }}=\mathbf{E m}_{12} / \hat{\mathbf{G}}_{\mathrm{g}}$

\section{HASIL DAN PEMBAHASAN}

\section{Inklusifitas Pertumbuhan Ekonomi}

Pertumbuhan ekonomi disebut inklusif apabila pertumbuhan mampu menurunkan kemiskinan, menurunkan ketimpangan dan menyerap tenaga kerja. Analisis inklusifitas pertumbuhan ekonomi dalam penelitian ini dibagi dalam beberapa sub bahasan. Tiga bagian pertama menguraikan inklusifitas pertumbuhan pada masingmasing indikator, yaitu kemiskinan, ketimpangan dan penyerapan tenaga kerja. Bagian selanjutnya menguraikan fenomena pertumbuhan inklusif di Indonesia Bagian Barat (IBB) dan Indonesia Bagian Timur (IBT).

\section{Inklusifitas Pertumbuhan Ekonomi dalam Menurunkan Kemiskinan}

Menurunkan

kemiskinan

merupakan salah satu tolak ukur bagi pertumbuhan ekonomi untuk dapat disebut sebagai pertumbuhan yang inklusif. Dalam penelitian ini, inklusifitas pertumbuhan ekonomi dalam menurunkan kemiskinan dinilai dengan koefisien inklusifitas untuk kemiskinan $\left(\mathrm{IG}_{\mathrm{p}}\right)$. Lampiran 1 menunjukkan perbandingan koefisien inklusifitas pertumbuhan ekonomi terhadap kemiskinan dengan pertumbuhan ekonomi yang direpresentasikan dari perubahan PDRB 33 provinsi di Indonesia pada tahun 2008-2012.

Pertumbuhan ekonomi dikatakan inklusif apabila koefisien inklusifitas pertumbuhan terhadap kemiskinan $\left(\mathrm{IG}_{\mathrm{p}}\right)$ memiliki nilai yang lebih besar dari pertumbuhan ekonomi $\left(\mathrm{G}_{\mathrm{g}}\right)$. Dari Lampiran 1 dapat dilihat bahwa sepanjang periode pengamatan, tahun 2008-2012, tidak satupun provinsi yang konsisten memiliki pertumbuhan yang inklusif dalam menurunkan kemiskin. Lampiran 1 menunjukkan bahwa koefisien inklusifitas yang dimiliki setiap provinsi cenderung fluktuatif. Pada tahun 2008 provinsi Sumatera Utara, Jawa Tengah, DI Yogyakarta (DIY), dan Papua Barat memiliki pertumbuhan yang inklusif dalam menurunkan kemiskinan. Pada tahun 2009, tidak satupun provinsi memiliki pertumbuhan yang inklusif dalam menurunkan kemiskinan.

Di tahun berikutnya, yaitu tahun 2010, provinsi Nusa Tenggara Barat (NTB), Nusa Tenggara Timur (NTT), Kalimantan Barat, Kalimantan Tengah, Kalimantan Timur, dan Sulawesi Selatan adalah provinsi-provinsi yang memiliki pertumbuhan inklusif terhadap menurunkan kemiskinan. Provinsi Kalimantan Barat mampu mempertahankan kualitas pertumbuhannya sehingga inklusif dalam menurunkan kemiskinan selama dua tahun berikutnya, yaitu tahun 2011 . Dan 2012. Sedangkan provinsi Sulawesi Utara dan Sulawesi Tengah memiliki pertumbuhan yang inklusif dalam menurunkan kemiskinan selama dua tahun berturut-turut, sejak tahun 2011 hingga 2012.

Sebagian besar provinsi di Indonesia memiliki pertumbuhan yang tidak inklusif dalam menurunkan kemiskinan. Meskipun demikian, terdapat provinsi-provinsi yang 
memiliki koefisien inklusifitas pertumbuhan terhadap kemiskinan dengan nilai positif. Koefisien inklusifitas yang bernilai positif namun lebih kecil dari pertumbuhan ekonomi artinya penurunan kemiskinan tetap terjadi seiring dengan meningkatnya pertumbuhan ekonomi. Hasil pertumbuhan tidak didistribusikan secara merata namun manfaat pertumbuhan ekonomi tetap diterima oleh penduduk yang tidak miskin. Lampiran 1 menunjukkan bahwa sepanjang periode pengamatan, tahun 2008-2012, terdapat 14 provinsi yang sepanjang 5 tahun terus memiliki koefisien inklusifitas positif namun lebih kecil dari pertumbuhan ekonomi. Provinsi-provinsi tersebut adalah Sumatera Barat, Sumatera Selatan, Bengkulu, Lampung, Kep. Bangka Belitung, DKI Jakarta, Jawa Barat, Banten, Bali, Kalimantan Selatan, Sulawesi Tenggara, Gorontalo, Sulawesi Barat, dan Maluku Utara. Pada tahun 2008 provinsi Sumatera Barat, Riau, Sumatera Selatan, Bengkulu, Lampung, Kep. Bangka Belitung, DKI Jakarta, Jawa Barat, Jawa Timur, Banten, Bali, NTB, NTT, Kalimantan Barat, Kalimantan Tengah, Kalimantan Selatan, seluruh provinsi di Pulau Sulawesi, dan Maluku Utara memiliki koefisien inklusifitas dengan nilai positif. Jumlah provinsi dengan koefisien inklusifitas positif namun kurang dari pertumbuhan ekonominya semakin banyak ditahun 2009. Provinsi tersebut meliputi seluruh provinsi di Pulau Jawa, Bali dan Nusa Tenggara, serta Pulau Sulawesi, Maluku dan Papua. Di Sumatera, provinsi Sumatera Utara, Sumatera Barat, Jambi, Sumatera Selatan, Bengkulu, Lampung, dan Kep. Bangka Belitung juga memiliki koefisien inklusifitas bernilai positif. Sedangkan di Kalimantan terdapat 3 provinsi dengan koefisien inklusifitas bernilai positif, yaitu Kalimantan Barat, Kalimantan Tengah, dan Kalimantan Selatan.

Pada tahun berikutnya, tahun 2010, provinsi-provinsi di Pulau Jawa, dan Maluku belum mampu meningkatkan inklusifitas pertumbuhannya, sehingga seluruh provinsi di pulau tersebut memiliki koefisien inklusifitas yang positif namun kurang dari pertumbuhan ekonominya. Seluruh provinsi di pulau Sumatera dan Maluku juga memiliki koefisien pertumbuhan dengan nilai positif, diikuti oleh Bali, Sulawesi Utara, Sulawesi Tengah, Sulawesi Tenggara, Gorontalo, Sulawesi Barat, dan Papua Barat. Kondisi ini tidak banyak berubah untuk tahun 2011 dan 2012. Hanya provinsi Sulawesi Utara dan Sulawesi Tengah yang inklusifitas pertumbuhannya berubah di tahun 2011 . Selain dua provinsi tersebut seluruh provinsi yang koefisien inklusifitasnya bernilai positif di tahun 2010, ditambah provinsi Kalimantan Tengah, Kalimantan Timur, dan Sulawesi Selatan, masih terus berada pada posisi yang sama selama 2 tahun berikutnya, yaitu tahun 2011 dan 2012.

Koefisien pertumbuhan dapat bernilai negatif, yang artinya pertumbuhan ekonomi dinikmati oleh penduduk tidak miskin. Koefisien yang negatif juga berarti bahwa pertumbuhan ekonomi yang terjadi tidak mampu menjalankan peranannya dalam menurunkan kemiskinan, bahkan cenderung memperparah kemiskinan yang terjadi. Provinsi NAD, Kep. Riau, dan Kalimantan Timur, mengalami kondisi tersebut selama dua tahun berturut-turut, yaitu tahun 2008 dan 2009. Pada Tahun 2008, provinsi Jambi, Maluku dan Papua memiliki koefisien inklusifitas bernilai negatif, sedangkan provinsi Riau mengalami hal yang sama di tahun 2009. Provinsi Papua adalah 
satu-satunya provinsi dengan koefisien inklusifitas bernilai negatif pada tahun 2010. Pada tahun 2011 dan 2012, koefisien inklusifitas pertumbuhan dalam menurunkan kemiskinan di Papua masih bernilai negatif, begitu juga dengan provinsi NTB.

Sebagaimana yang terjadi pada provinsi-provinsi di Indonesia, koefisien inklusifitas pertumbuhan dalam menurunkan kemiskinan secara nasional memiliki nilai yang fluktuatif sepanjang periode pengamatan yaitu tahun 2008 hingga 2012. Jumlah provinsi yang pertumbuhannya inklusif dalam menurunkan kemiskinan jauh lebih sedikit dibanding provinsi yang pertumbuhannya tidak inklusif. Dengan kondisi demikian, pertumbuhan ekonomi di Indonesia dapat dikatakan tidak inklusif dalam menurunkan kemiskinan. Hal ini sesuai dengan koesifisien inklusifitas pertumbuhan dalam menurunkan kemiskinan di Indonesia yang dapat dilihat di Lampiran 1. Dari Lampiran 1, dapat dilihat bahwa sepanjang periode pengamatan koefisien inklusifitas Indonesia selalu bernilai positif namun tidak lebih besar dari pertumbuhan ekonomi yang terjadi di Indonesia.

\section{Inklusifitas Pertumbuhan Ekonomi dalam Menurunkan Ketimpangan}

Indikator ke dua dari pertumbuhan yang inklusif adalah kemampuan pertumbuhan ekonomi dalam menurunkan ketimpangan. Ketika pertumbuhan ekonomi yang ada hanya dapat dinikmati oleh sebagian kecil masyarakat maka ketimpangan terjadi. Dengan demikian maka pertumbuhan ekonomi dikatakan inklusif apabila pertumbuhan tersebut dapat mengurangi ketimpangan.

Pertumbuhan yang inklusif dalam menurunkan ketimpangan ditunjukkan oleh nilai koefisien inklusifitas pertumbuhan terhadap ketimpangan $\left(\mathrm{IG}_{\text {in }}\right)$ yang lebih besar dari pertumbuhan ekonomi $\left(\mathrm{G}_{\mathrm{g}}\right)$. Koefisien inklusifitas pertumbuhan terhadap ketimpangan 33 provinsi-provinsi di Indonesia pada tahun 2008 sampai 2012 dapat dilihat pada lampiran 2. Pada lampiran 2 juga dapat dilihat perbandingan antara koefisien inklusifitas pertumbuhan terhadap ketimpangan dengan pertumbuhan ekonomi.

Lampiran 2 menunjukkan bahwa pada periode pengamatan, tahun 20082012, tidak satupun provinsi yang mampu mempertahankan inklusifitas pertumbuhannya dalam menurunkan ketimpangan selama 5 tahun berturutturut. Provinsi yang pertumbuhan ekonominya inklusif terhadap ketimpangan pada tahun 2008 adalah provinsi Jawa Tengah, DIY, dan Papua Barat. Pada tahun 2009 tidak satupun provinsi yang pertumbuhannya inklusif dalam menurunkan ketimpangan. Provinsi NTB, NTT, Kalimantan Barat, Kalimantan Tengah, Kalimantan Timur, dan Sulawesi Selatan memiliki pertumbuhan yang inklusif terhadap ketimpangan di tahun 2010. Provinsi Kalimantan Barat kembali memiliki pertumbuhan yang inklusif pada tahun 2011. Selain provinsi tersebut, 2 provinsi lain yaitu Sulawesi Utara dan Sulawesi Tengah memiliki pertumbuhan yang inklusif dalam menurunkan ketimpangan selama 2 tahun berturut-turut yaitu tahun 2011 hingga 2012.

Koefisien

inklusifitas pertumbuhan ekonomi yang memiliki nilai yang positif namun lebih kecil dari pertumbuhan ekonomi menunjukkan bahwa ketimpangan tetap ada dalam perolehan manfaat pertumbuhan ekonomi. Dalam kondisi ini, pertumbuhan ekonomi yang terjadi tidak mampu mendistribusikan 
manfaatnya secara merata. Ketika hal ini terjadi, maka penurunan ketimpangan lebih kecil daripada laju peningkatan pertumbuhan ekonomi. Sepanjang tahun 2008 hingga 2012, mayoritas provinsi di Indonesia memiliki koefisien inklusifitas pertumbuhan terhadap ketimpangan yang nilainya positif namun lebih kecil dari pertumbuhan ekonomi. Dari lampiran 2 dapat dilihat bahwa selama 5 tahun berturut-turut (tahun 2008-2012) terdapat 5 provinsi yang koefisien inklusifitasnya bernilai positif dan lebih kecil dari pertumbuhan ekonomi. Provinsi-provinsi tersebut adalah Sumatera Selatan, Banten, Bali, Sulawesi Tenggara, dan Gorontalo.

Lampiran 2 menunjukkan bahwa pada tahun 2008 terdapat 18 provinsi dengan koefisien inklusifitas positif dan lebih kecil dari pertumbuhan ekonominya, yaitu provinsi Sumatera Barat, Riau, Sumatera Selatan, Bengkulu, Lampung, DKI Jakarta, Jawa Barat, Jawa Timur, Banten, Bali, NTT, Kalimantan Tengah, Kalimantan Selatan, Sulawesi Utara, Sulawesi Tengah, Sulawesi Selatan, Sulawesi Tenggara, dan Gorontalo. Jumlah ini meningkat di tahun 2009 dimana terdapat 24 provinsi dengan koefisien inklusifitas pertumbuhan yang positif namun kurang dari pertumbuhan ekonomi. Provinsi tersebut adalah Sumatera Utara, Sumatera Barat, Jambi, Sumatera Selatan, Bengkulu, Kep. Bangka Belitung, Bali, NTB, NTT, Kalimantan Barat, Kalimantan Selatan, serta seluruh provinsi di Pulau Jawa, Sulawesi dan Papua.

Begitu juga pada tahun 2010, terdapat 22 provinsi dengan koefisien inklusifitas bernilai positif namun kurang dari pertumbuhan ekonomi, yaitu provinsi NAD, Sumatera Utara, Sumatera Barat, Jambi, Sumatera Selatan, Bengkulu, Lampung, Kep.
Bangka Belitung, Jawa Tengah, DIY, Jawa Timur, Banten, Bali, Kalimantan Selatan, Sulawesi Utara, Sulawesi Tengah, Sulawesi Tenggara, Gorontalo, Sulawesi Barat, Maluku, Maluku Utara, dan Papua Barat. Jumlah ini kembali meningkat pada tahun 2011, dimana terdapat 25 provinsi dengan koefisien inklusifitas bernilai positif dan kurang dari pertumbuhan ekonomi. Provinsiprovinsi tersebut adalah provinsi NAD, Sumatera Barat, Riau, Jambi, Sumatera Selatan, Bengkulu, Lampung, Kep. Riau, Bali, NTT, Kalimantan Tengah, Kalimantan Timur, Sulawesi Selatan, Sulawesi Tenggara, Gorontalo, Sulawesi Barat, Maluku, Maluku Utara, dan Papua Barat. Terakhir ditahun 2012 , terdapat 25 provinsi yang masuk dalam kelompok provinsi dengan koefisien inklusifitas positif dan kurang dari pertumbuhan ekonomi. Provinsi tersebut adalah NAD, Sumatera Utara, Riau, Jambi, Sumatera Selatan, Lampung, Kep. Bangka Belitung, Kep. Riau, Jawa Barat, Jawa Tengah, DIY, Jawa Timur, Banten, Bali, Kalimantan Tengah, Kalimantan Selatan, Kalimantan Timur, Sulawesi Selatan, Sulawesi Tenggara, Gorontalo, Sulawesi Barat, Maluku, Maluku Utara, dan Papua Barat.

Beberapa provinsi memiliki koefisien inklusifitas pertumbuhan yang negatif terhadap ketimpangan. Dengan koefisien yang nilainya negatif, maka pertumbuhan ekonomi yang ada cenderung meningkatkan ketimpangan yang terjadi. Manfaat pertumbuhan ekonomi terus diberikan pada masyarakat secara tidak merata dan ketimpangan terus meningkat seiring dengan peningkatan pertumbuhan ekonomi. Pada Lampiran 2, terlihat bahwa provinsi Jambi, Kalimantan Timur, Maluku, dan Papua memiliki koefisien inklusifitas pertumbuhan terhadap ketimpangan yang nilainya 
negatif. Provinsi NAD, Riau, Kep. Riau, dan Kalimantan Timur juga memiliki koefisien inklusifitas dengan nilai negatif yaitu pada tahun 2009. Pada tahun 2010, Papua adalah satu-satunya provinsi dengan koefisien inklusifitas yang nilainya negatif. Kondisi ini terus berlanjut di Papua hingga tahun 2012. Sedangkan provinsi NTB memiliki koefisien inklusifitas pertumbuhan terhadap ketimpangan yang negatif selama 2 tahun berturut-turut, yaitu tahun 2011 dan 2012.

Tidak seperti penghitungan koefisien inklusifitas yang lain, pada penghitungan koefisien inklusifitas pertumbuhan ekonomi terhadap ketimpangan terdapat beberapa nilai yang tidak teridentifikasi (hasil perhitungan error karena adanya pembagian dengan nilai nol). Hal ini terjadi pada periode dimana ketimpangan, yang dinyatakan oleh koefisien gini, tidak mengalami perubahan dibanding periode sebelumnya. Dengan tidak adanya perubahan maka dapat dikatakan bahwa tidak terjadi perubahan ketimpangan antar periode. Provinsi dengan koefisien yang demikian memiliki nilai NA sebagaimana terlihat dalam lampiran 2 .

Seperti pertumbuhan ekonomi di provinsi yang setiap tahun nilainya berfluktuasi, koefisien inklusifitas pertumbuhan dalam menurunkan ketimpangan pada provinsi-provinsi di Indonesia juga mengalami hal yang sama. Jumlah provinsi dengan pertumbuhan yang inklusif jauh lebih sedikit dibanding provinsi yang pertumbuhannya tidak inklusif. Dengan kondisi ini, secara nasional dapat dilihat bahwa sepanjang periode pengamatan pertumbuhan ekonomi di Indonesia selalu tidak inklusif dalam menurunkan ketimpangan. Hal ini dapat ditunjukkan oleh lampiran 2, dimana koefisien inklusifitas pertumbuhan dalam menurunkan ketimpangan sepanjang tahun 2008 hingga 2011 bernilai positif namun lebih kecil dari pertumbuhan ekonomi. Sedangkan akibat ketimpangan yang tidak berubah pada tahun 2012, maka pada tahun tersebut koefisien inklusifitas pertumbuhan dalam menurunkan ketimpangan secara nasional tidak dapat dihitung.

\section{Inklusifitas Pertumbuhan Ekonomi dalam Penyerapan Tenaga Kerja}

Pertumbuhan ekonomi disebut inklusif apabila pertumbuhan tersebut mampu menurunkan kemiskinan, menurunkan ketimpangan, dan menyerap lebih banyak tenaga kerja. Dua indikator pertama telah diuraikan pada penjelasan sebelumnya. Indikator ketiga yaitu penyerapan tenaga kerja menggunakan konsep yang sama untuk mengukur inklusifitas pertumbuhan ekonomi, yaitu dengan menggunakan koefisien inklusifitas pertumbuhan terhadap penyerapan tenaga kerja.

Koefisien inklusifitas pertumbuhan terhadap tenaga kerja $\left(\mathrm{IG}_{\mathrm{em}}\right)$ yang nilainya lebih besar dari pertumbuhan ekonomi $\left(\mathrm{G}_{\mathrm{g}}\right)$ menunjukkan bahwa pertumbuhan ekonomi inklusif dalam penyerapan tenaga kerja. Koefisien tersebut ditunjukkan di Lampiran 3. Pada Lampiran 3 dapat dilihat perbandingan antara koefisien inklusifitas pertumbuhan terhadap penyerapan tenaga kerja dengan perumbuhan ekonomi yang dihitung dari laju perubahan PDRB 33 provinsi di Indonesia pada tahun 2008-2012.

Lampiran 3 menunjukkan bahwa provinsi NAD, Sumatera Utara, Kep. Riau, DKI Jakarta, DIY, Kalimantan Timur, Gorontalo, Maluku Utara, Papua Barat, dan Papua memiliki koefisien inklusifitas pertumbuhan yang nilainya lebih besar dari pertumbuhan ekonomi. Pada tahun 2009, terdapat 3 provinsi 
yang memiliki koefisien inklusifitas lebih besar dari pertumbuhan ekonomi, provinsi tersebut adalah NAD, Kalimantan Timur, dan Maluku. Terdapat 17 provinsi dengan koefisien inklusifitas yang nilainya lebih besar dari pertumbuhan ekonomi pada tahun 2010, yaitu provinsi Riau, Jambi, Sumatera Selatan, Sumatera Utara, Lampung, Kep. Bangka Belitung, Kep. Riau, DKI Jakarta, Banten, NTB, NTT, Kalimantan Barat, Kalimantan Tengah, Kalimantan Timur, Sulawesi Selatan, Maluku dan Papua.

Pada tahun 2011 provinsi yang koefisien inklusifitasnya lebih besar dari pertumbuhan ekonomi, yaitu provinsi Riau, Kalimantan Barat, Sumatera Utara, Kalimantan Timur, Kalimantan Tengah, Sulawesi Tengah, dan Maluku. Jumlah ini jauh berkurang pada tahun 2012, hanya 2 provinsi yang koefisien inklusifitasnya bernilai positif, yaitu Kalimantan Barat dan Papua. Provinsiprovinsi dengan nilai koefisien inklusifitas pertumbuhan terhadap penyerapan tenaga kerja yang nilainya lebih besar dari pertumbuhan ekonomi menunjukkan bahwa pertumbuhan ekonomi yang terjadi telah mampu menyerap lebih banyak tenaga kerja. Artinya, pertumbuhan ekonomi di provinsi-provinsi tersebut adalah pertumbuhan yang inklusif dalam penyerapan tenaga kerja.

Kondisi sebaliknya terjadi pada provinsi dengan nilai koefisien inklusifitas negatif. Dengan koefisien inklusifitas yang negatif, pertumbuhan ekonomi yang terjadi diiringi dengan berkurangnya penyerapan tenaga kerja. Pertumbuhan ekonomi tidak mampu menciptakan lapangan kerja baru bagi penduduk yang sudah masuk dalam angkatan kerja. Pada lampiran 3, koefisien inklusifitas pertumbuhan terhadap penyerapan tenaga kerja yang nilainya negatif terjadi di provinsi Jawa
Tengah, NTB, dan Sulawesi Utara untuk tahun 2008. Di tahun berikutnya, tahun 2009, hanya DKI Jakarta yang koefisien inklusifitasnya bernilai negatif. Pada tahun 2010, terdapat 8 provinsi yang memiliki koefisien inklusifitas pertumbuhan terhadap penyerapan tenaga kerja yang nilainya negatif. Provinsi tersebut adalah Jawa Barat, Jawa Tengah, DIY, Jawa Timur, NTT, Sulawesi Utara, dan Papua Barat. Provinsi Sumatera Utara, Jambi, Lampung, Kep. Bangka Belitung, DKI Jakarta, Banten, dan NTB memiliki koefisien inklusifitas pertumbuhan terhadap penyerapan tenaga kerja bernilai negatif pada tahun 2011. Sedangkan pada tahun 2012, hanya dua provinsi yang koefisien inklusifitasnya negatif, yaitu provinsi Kalimantan Selatan dan Maluku.

Sama halnya dengan dua indikator pertumbuhan inklusif yang telah dijelaskan sebelumnya, mayoritas provinsi di Indonesia selama periode pengamatan memiliki koefisien pertumbuhan inklusif bernilai positif namun lebih kecil dari pertumbuhan ekonomi. Dalam konteks penyerapan tenaga kerja, hal ini berarti bahwa pertumbuhan ekonomi yang terjadi mampu meningkatkan penyerapan tenaga kerja tetapi peningkatan pertumbuhan ekonomi terjadi lebih cepat dibanding peningkatan penyerapan tenaga kerja. Pada Lampiran 3, provinsi yang koefisien inklusifitasnya positif dan lebih kecil dari pertumbuhan ekonomi sepanjang periode pengamatan, tahun 2008-2012, adalah provinsi Sumatera Barat, Bengkulu, Bali, dan Sulawesi Barat.

Pada tahun 2008, provinsi yang koefisien inklusifitasnya bernilai positif adalah Sumatera Barat, Jambi, Sumatera Selatan, bengkulu, Lampung, Kep. Bangka Belitung, Jawa Barat, Jawa Timur, Banten, Bali, NTT, 
Kalimantan Barat, Kalimantan Tengah, Kalimantan Selatan, Sulawesi Tengah, Sulawesi Selatan, Sulawesi Tenggara, Sulawesi Barat dan Maluku. Provinsi Sumatera Barat, Jambi, Sumatera Selatan, Lampung, Kep. Bangka Belitung, Jawa Barat, Jawa Timur, Banten, Bali, NTT, Kalimantan Barat, Kalimantan Tengah, Kalimantan Selatan, dan Maluku.

Jumlah provinsi dengan koefisien inklusifitas positif namun kurang dari pertumbuhan ekonomi meningkat menjadi 28 provinsi pada tahun 2009 . Provinsi tersebut adalah Sumatera Utara, Sumatera Barat, Riau, Jambi, Bengkulu, Lampung, Kep. Bangka Belitung, Kep. Riau, Jawa Barat, Jawa Tengah, DIY, Jawa Timur, Banten, Bali, NTB, NTT, Kalimantan Barat, Kalimantan Tengah, Kalimantan Selatan, seluruh provinsi di Pulau Sulawesi, Maluku Utara, Papua Barat, dan Papua. Sedangkan pada tahun 2010, terdapat 11 provinsi dengan koefisien inklusifitas bernilai positif dan kurang dari pertumbuhan ekonomi, yaitu provinsi NAD, Sumatera Utara, Sumatera Barat, Bengkulu, Bali, Kalimantan Selatan, Sulawesi Tengah, Sulawesi Tenggara, Gorontalo, Sulawesi Barat, dan Maluku Utara. Pada tahun 2011, jumlah ini kembali meningkat menjadi 18 provinsi, yaitu provinsi NAD, Sumatera Barat, Sumatera Selatan, Bengkulu, Kep. Riau, Jawa Barat, Jawa Tengah, Jawa Timur, Bali, NTT, Kalimantan Selatan, Sulawesi Utara, Sulawesi Selatan, Sulawesi Tenggara, Gorontalo, Sulawesi Barat, Maluku Utara, dan Papua Barat. Tahun 2012 jumlah provinsi dengan koefisien inklusifitas bernilai positif dan kurang dari pertumbuhan ekonomi adalah seluruh provinsi di Pulau Sumatera, Jawa, Sulawesi, bali dan Nusa Tenggara, serta provinsi Kalimantan Tengah,
Kalimantan Timur, Maluku Utara dan Papua Barat. Maka jika diamati, setidaknya sejak tahun 2011 pertumbuhan ekonomi provinsi-provinsi di Indonesia semakin tidak inklusif terhadap penyerapan tenaga kerja.

Sama halnya dengan inklusifitas pertumbuhan dalam menurunkan kemiskinan dan menurunkan ketimpangan, dalam meningkatkan penyerapan tenaga kerja koefisien inklusifitas pertumbuhan provinsiprovinsi di Indonesia berfluktuasi setiap tahunnya. Provinsi dengan pertumbuhan yang inklusif jumlahnya lebih sedikit dibandingkan provinsi yang tidak inklusif selama 5 tahun periode pengamatan. Dengan mayoritas provinsi yang pertumbuhannya tidak inklusif, maka pertumbuhan ekonomi di Indonesia dapat dikatakan tidak inklusif dalam meningkatkan penyerapan tenaga kerja. Hal ini juga terlihat dari koefisien inklusifitas secara nasional yang nilainya selalu lebih kecil dari pertumbuhan ekonomi sebagaimana dapat dilihat pada lampiran 3 .

\section{Fenomena Pertumbuhan Inklusif di Indonesia Bagian Barat dan Timur}

Untuk menjelaskan fenomena pertumbuhan inklusif antar kawasan di Indonesia, penelitian membagi Indonesia menjadi 2 wilayah yaitu Indonesia Bagian Barat (IBB) dan Indonesia Bagian Timur (IBT). Dalam penelitian ini, wilayah Indonesia Bagian Barat (IBB) terdiri dari seluruh provinsi di Pulau Sumatera dan Jawa yang berjumlah 16 provinsi. Provinsiprovinsi tersebut adalah NAD, Sumatera Utara, Sumatera Barat, Riau, Jambi, Sumatera Selatan, Bengkulu, Lampung, Kep. Bangka Belitung, Kep. Riau, DKI Jakarta, Jawa Barat, Jawa Tengah, DIY, Jawa Timur, dan Banten. Sedangkan wilayah Indonesia Bagian Timur (IBT) terdiri dari seluruh 
provinsi di Pulau Kalimantan, Bali dan Nusa Tenggara, Sulawesi, Maluku dan Papua yang terdiri dari 17 provinsi. Provinsi yang masuk dalam IBT adalah provinsi Bali, Nusa Tenggara Barat, Nusa Tenggara Timur, Kalimantan Barat, Kalimantan Tengah, Kalimantan Selatan, Kalimantan Timur, Sulawesi Utara, Sulawesi Tengah, Sulawesi Selatan, Sulawesi Tenggara, Gorontalo, Sulawesi Barat, Maluku, Maluku Utara, Papua Barat dan Papua.

Pembahasan mengenai inklusifitas pertumbuhan ekonomi dalam menurunkan kemiskinan, mengurangi ketimpangan, dan meningkatkan penyerapan tenaga kerja yang telah diuraikan sebelumnya menghasilkan informasi mengenai provinsi-provinsi dengan koefisien inklusifitas masingmasing selama periode pengamatan. Suatu provinsi dapat memiliki pertumbuhan yang inklusif untuk indikator tertentu pada tahun tertentu, kemudian dengan koefisien yang berubah maka inklusifitasnya pun dapat berubah di waktu yang lain. Perubahan koefisien inklusifitas terjadi baik di kawasan IBB maupun IBT. Provinsi yang memiliki pertumbuhan yang inklusif untuk setiap indikator juga tersebar di kawasan IBB dan IBT. Gambar 2 menunjukkan jumlah provinsi dalam IBB dan IBT yang memiliki pertumbuhan yang inklusif dalam menurunkan kemiskinan pada tahun 2008-2012.

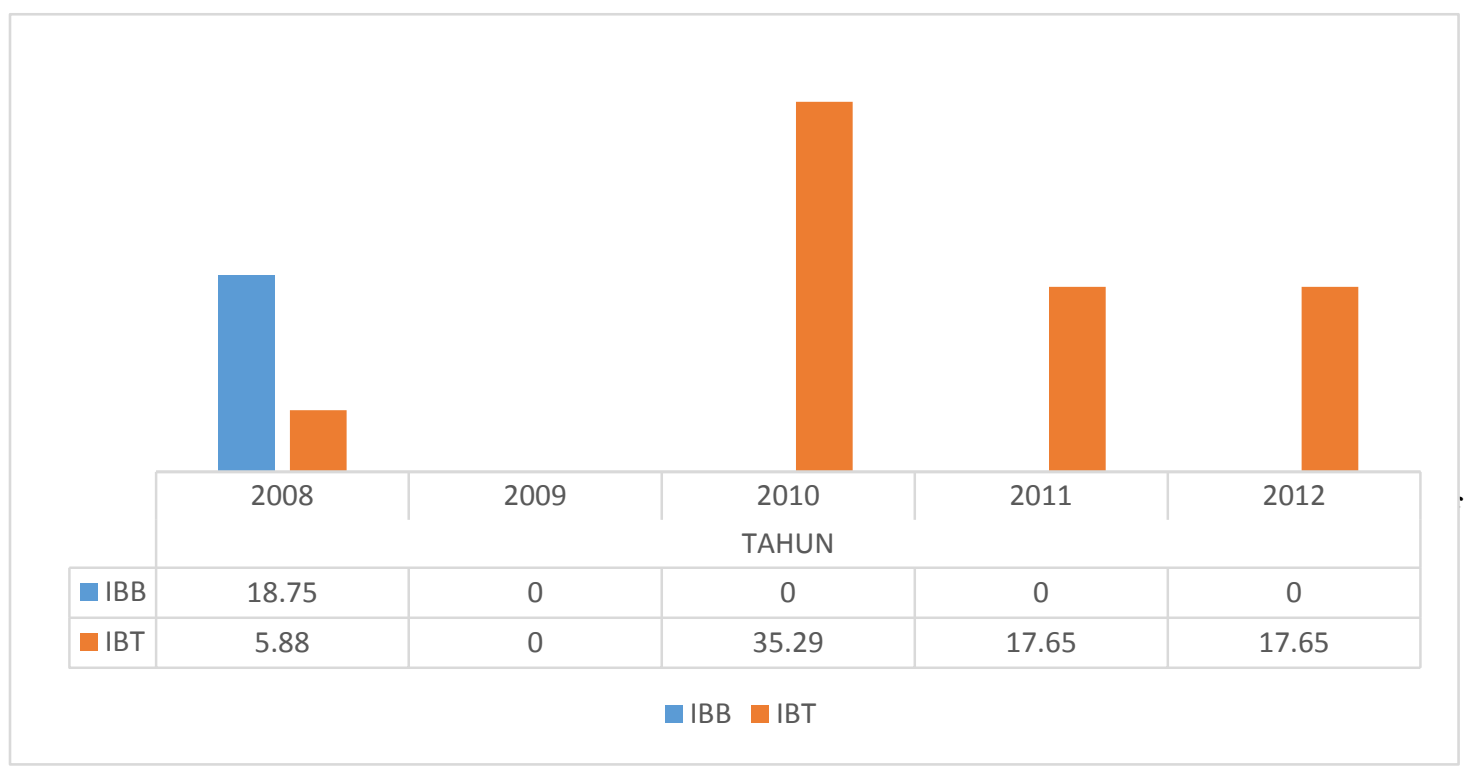

Gambar 2. Jumlah Propinsi dalam IBB dan IBT tahun 2008-2012

Dari Gambar 2 dapat dilihat bahwa pada tahun 2008, sebesar 18,75 persen provinsi yang berada di kawasan IBB memiliki pertumbuhan yang inklusif dalam menurunkan kemiskinan, sedangkan di IBT hanya 5,88 persen provinsi dalam kawasan ini yang pertumbuhannya inklusif dalam menurunkan kemiskinan. Pada tahun
2009, tidak satupun provinsi di IBB dan IBT yang pertumbuhan ekonominya inklusif dalam menurunkan kemiskinan. Kondisi tersebut terus terjadi di IBB hingga akhir periode pengamatan yaitu tahun 2012. Sebaliknya di IBT, jumlah provinsi yang pertumbuhan ekonominya inklusif dalam menurunkan kemiskinan mencapai angka tertinggi di tahun 2010, 
yaitu sebesar 35,29 persen. Jumlah ini menurun menjadi 17,65 persen pada tahun 2011 dan tidak berubah sampai tahun 2012.

Gambar 6 menunjukkan bahwa sepanjang periode pengamatan jumlah provinsi yang pertumbuhannya inklusif dalam menurunkan kemiskinan di IBT lebih besar dibanding IBB. Hal ini menunjukkan bahwa pertumbuhan ekonomi di IBT lebih inklusif dalam menurunkan kemiskinan dibandingkan di IBB.

Provinsi dengan pertumbuhan ekonomi yang inklusif dalam menurunkan ketimpangan juga tersebar di kawasan IBB dan IBT. Jumlah provinsi yang pertumbuhannya inklusif dalam menurunkan ketimpangan di kawasan IBB dan IBT pada tahun 20082012 dapat dilihat di Gambar 7.

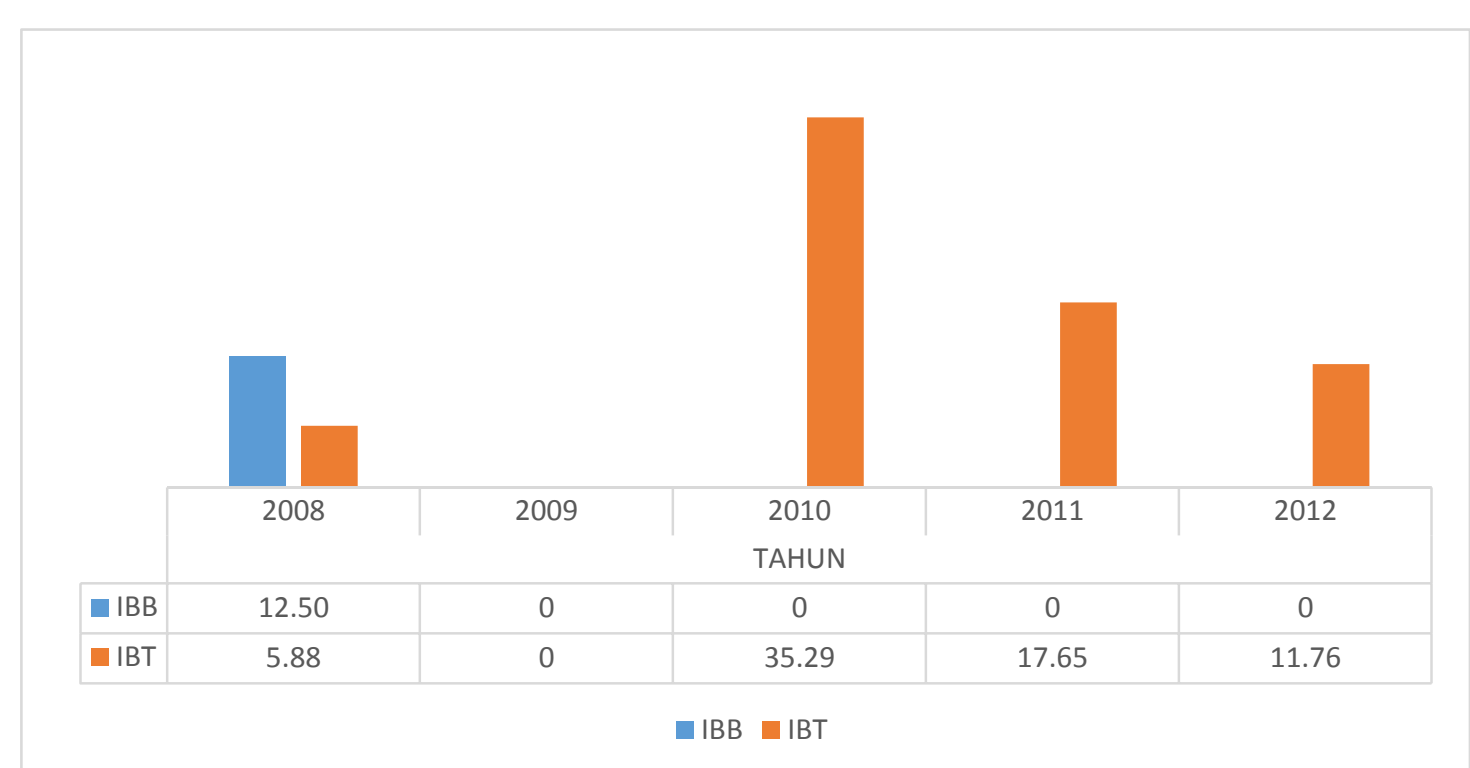

Gambar 3. Persentase Jumlah Provinsi yang Pertumbuhan Ekonominya Inklusif dalam Menurunkan Ketimpangan di Wilayah Indonesia Barat dan Timur pada Tahun 2008-2012.

Gambar 3 menunjukkan persentase jumlah provinsi yang pertumbuhannya inklusif dalam menurunkan kemiskinan di IBB dan IBT memiliki nilai yang berbeda sepanjang periode pengamatan, yaitu tahun 2008-2012. Pada tahun 2008, sebesar 12,50 persen provinsi yang masuk dalam IBB memiliki pertumbuhan yang inklusif dalam menurunkan ketimpangan. Angka tersebut lebih besar dibanding di IBT yang hanya 5,88 persen provinsinya yang memiliki pertumbuhan inklusif dalam menurunkan ketimpangan. Sedangkan pada tahun 2009, tidak satupun provinsi dalam IBB dan IBT yang pertumbuhannya inklusif dalam menurunkan ketimpangan. Pada tahun 2010, sebanyak 35,29 persen provinsi dalam IBT memiliki pertumbuhan yang inklusif dalam menurunkan ketimpangan. Jumlah ini menurun drastis menjadi 17,65 persen pada tahun 2011 dan terus turun menjadi 11,76 persen pada tahun 2012. Meskipun menurun, namun kondisi di IBT lebih baik dibanding IBB yang tidak satupun provinsinya memiliki pertumbuhan yang inklusif dalam menurunkan ketimpangan sejak tahun 2009 hingga 2012.

Dari Gambar 2 dan Gambar 3 terlihat bahwa antara persentase 


$\begin{array}{lcrl}\text { inklusifitas } & \text { pertumbuhan } & \text { dalam } & \text { berbeda terjadi pada inklusifitas } \\ \text { menurunkan } & \text { kemiskinan } & \text { dengan } & \text { pertumbuhan dalam meningkatkan } \\ \text { inklusifitas } & \text { pertumbuhan } & \text { dalam } & \text { penyerapan tenaga kerja di IBB dan IBT } \\ \text { menurunkan } & \text { ketimpangan di IBB dan } & \text { seperti terlihat pada Gambar } 4 .\end{array}$

IBT pada tahun 2008-2012 dapat dikatakan tidak jauh berbeda. Hal yang

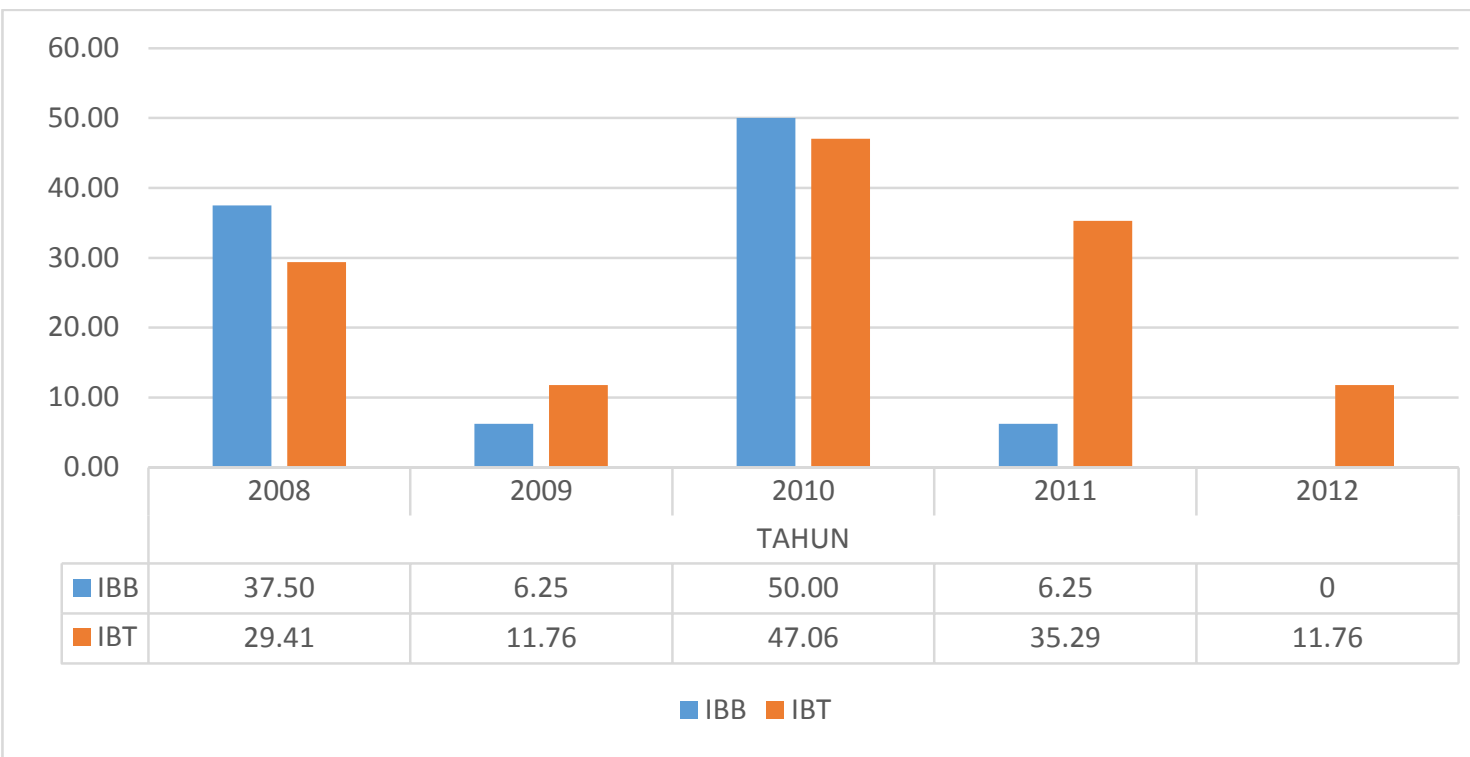

Gambar 4. Persentase Jumlah Provinsi yang Pertumbuhan Ekonominya Inklusif dalam Meningkatkan Penyerapan Tenaga Kerja di Wilayah Indonesia Barat dan Timur pada Tahun 2008-2012.

Gambar 4 menunjukkan bahwa 37,50 persen provinsi di IBB memiliki pertumbuhan yang inklusif dalam meningkatkan penyerapan tenaga kerja pada tahun 2008. Pada tahun yang sama, provinsi yang pertumbuhannya inklusif dalam meningkatkan penyerapan tenaga kerja di IBT adalah sebesar 29,41 persen. Baik di IBB maupun IBT, persentase provinsi yang pertumbuhannya inklusif dalam meningkatkan penyerapan tenaga kerja menurun pada tahun 2009. Hanya 6,25 persen provinsi di IBB yang pertumbuhannya inklusif, sedangkan di IBT sedikit lebih besar yaitu 11,76 persen. Pada tahun 2010, terdapat 50 persen provinsi dalam IBB yang pertumbuhannya inklusif dalam meningkatkan penyerapan tenaga kerja. Sedangkan di IBT, angkanya sedikit lebih rendah yaitu 47,06 persen. Di IBB pada tahun 2011, hanya 6,25 persen provinsi yang pertumbuhannya inklusif dalam meningkatkan penyerapan tenaga kerja. Bahkan pada tahun 2012, tidak satupun provinsi dalam kawasan tersebut yang memiliki pertumbuhan yang inklusif dalam meningkatkan penyerapan tenaga kerja. Sedangkan di IBT, meskipun terjadi penurunan, persentase provinsi dengan pertumbuhan yang inklusif masih lebih besar dibanding IBB yaitu 35,29 persen pada tahun 2011 dan 11,76 persen pada tahun 2012.

Dari Gambar 2, Gambar 3, dan Gambar 4 dapat dilihat bahwa provinsiprovinsi yang masuk dalam IBT memiliki pertumbuhan ekonomi yang lebih inklusif untuk setiap indikator dibandingkan di IBB. Hal ini dapat 
disebabkan oleh adanya orientasi dan perhatian yang lebih besar terhadap kawasan IBT sebagai konsekuensi prinsip pemerataan pembangunan. Meskipun demikian, di IBT terdapat kecenderungan adanya penurunan jumlah provinsi yang pertumbuhannya inklusif untuk setiap indikator terutama sejak tahun 2011. Perlu diingat pula bahwa meskipun di IBT persentase jumlah provinsi yang pertumbuhannya inklusif lebih besar dibanding IBB, namun persentase tersebut disumbang oleh provinsi yang berbeda antar tahun. Tidak satupun provinsi dalam IBB dan IBT yang konsisten memiliki pertumbuhan yang inklusif untuk semua indikator di sepanjang periode pengamatan.

\section{KESIMPULAN}

Berdasarkan hasil analisis yang telah dilakukan, kesimpulan yang dapat diperoleh dari penelitian ini adalah :

1. Pertumbuhan ekonomi di Indonesia pada tahun 2008-2012 belum inklusif dalam menurunkan kemiskinan, menurunkan ketimpangan, dan meningkatkan penyerapan tenaga kerja. Provinsi DIY dan Papua Barat adalah provinsi yang pertumbuhannya inklusif untuk semua indikator pada tahun 2008. Provinsi NTB, NTT, Kalimantan Barat, Kalimantan Tengah, Kalimantan Timur, dan Sulawesi Selatan adalah provinsi yang pertumbuhannya inklusif untuk semua indikator pada tahun 2010. Provinsi Kalimantan Barat dan Sulawesi Tengah adalah provinsi yang pertumbuhannya inklusif untuk semua indikator pada tahun 2011. Sedangkan pada tahun 2009 dan 2012 tidak satupun provinsi yang memiliki pertumbuhan yang inklusif dalam menurunkan kemiskinan, menurunkan ketimpangan, dan meningkatkan penyerapan tenaga kerja.

2. Pertumbuhan yang inklusif dalam menurunkan kemiskinan, menurunkan ketimpangan, dan meningkatkan penyerapan tenaga kerja bukan fenomena yang konsisten di Indonesia.

3. Fenomena pertumbuhan inklusif dalam menurunkan kemiskinan, menurunkan ketimpangan, dan meningkatkan penyerapan tenaga kerja lebih banyak terjadi di wilayah Indonesia Bagian Barat (IBB). Meskipun demikian, persentase jumlah provinsi di IBB memiliki kecenderungan semakin menurun terutama sejak tahun 2010 .

\section{DAFTAR PUSTAKA}

Ali, Ifzal. 2007. Inequality and the Imperative for Inclusive Growth in Asia. Asian Development Bank.

Ali, Ifzal dan Hyun Hwa Son. 2007. Measuring Inclusive Growth. Asian Development Review Vol. 24, No. 1, pp. 11-31. Manila: ADB.

Ansori, Mohammad Hasan. 2009. Consumerism and the Emergence of a New Middle Class in Globalizing Indonesia. EXPLORATIONS a graduate student journal of southeast asian studies, University of Hawai'i.

Arsyad, Lincolyn. 1999. Pengantar dan Perencanaan Pembangunan Ekonomi Daerah. BPFE : Yogyakarta.

Wie, T.K. 1983. Pembangunan Ekonomi dan Pemerataan, Beberapa Pendekatan Alternatif. LP3ES : Jakarta. 
Asian Development Bank. 2010. Key Indicators for Asia and the Pacific. Asian Development Bank : Mandaluyong City, Philippines.

Birdsall, Nancy. 2007. Reflections on the Macro Foundations of the Middle Class in theDeveloping World. Center for Global Development Working Paper 130, Washington DC. 2010.

The

(Indispensable) Middle Class in Developing Countries; or, The Rich and the Rest, Not the Poor and the Rest. Center for Global Development Working Paper 207, Washington DC.

Habito, Cielito F. 2009. Patterns of Inclusive Growth in Developing Asia:Insights from an Enhanced Growth-Poverty Elasticity Analysis. Asian Development Bank Institute (ADBI) working paper series No. 145, Tokyo.

Ianchovichina, Elena dan Sussana Lundstrom. 2009. Inclusive Growth Analytics Framework and Application. Policy Research Working Paper 4851, The World Bank Economic Policy and Debt DepartmentEconomic Policy Division.

Kakwani, N. dan H. Son. 2008. Poverty Equivalent Growth Rate. Review of Income and Wealth 54(4): 643-655.

Kharas, Homi. 2010. The Emerging Middle Class in Developing Countries. OECD

Development Centre, Working Paper No. 285.

Klasen, Stephen. 2010. Measuring and Monitoring Inclusive Growth: Multiple Definitions, Open Questions, and Some
Constructive Proposals. ADB

Sustainable Development Working Paper Series.

Mankiw, N.G. 2003. Teori Makroekonomi (edisi kelima), Penerbit Erlangga, Jakarta.

McDowell, D. R dan Joyce E. 1995. Poverty Among Southern Workers: Metro and NonMetro Differentials. Journal Agricultural Economic, 77: 796- 802.

Min Tang. 2008. Inclusive Growth and the New Phase of Poverty Reduction in the People's Republic of China. Asian Development Review, vol. 25, nos. 1 and 2, pp. 81-99.

Özbudun, Ergun. 2005. The Role of the Middle Class in the Emergence and Consolidation of a Democratic Civil Society. Ankara Law Review Vol.2 No.2 (Winter 2005), pp.95107.

Rusastra, I Wayan. 2011. Reorientasi Paradigma dan Strategi Pengentasan Kemiskinan Dalam Mengatasi Dampak Krisis Ekonomi Global. Pengembangan Inovasi Pertanian 4(2) : 87-102. Pusat Sosial Ekonomi dan Kebijakan Pertanian: Bogor.

Rusastra, I W. and Erwidodo. 1998. Growth, equity and environmental aspect of agricultural development in Indonesia. Forum Penelitian Agro Ekonomi 6(1): 32-41.

Ravallion, Martin. 2010. The Developing World's Bulging (but Vulnerable) Middle Class. World Development Vol. 38, No. 4, pp. 445-454.

Suryanarayana, M.H. 2008. Inclusive Growth: What is so exclusive about it?. Indira Gandhi 
Institute of Development

Research, Mumbai.

Todaro, Michael. 2000. Pembangunan

Ekonomi di Dunia Ketiga, edisi kesembilan

terjemahan

Munandar, Haris. Bumi Aksara :

Jakarta. 
Lampiran 1. Koefisien Inklusifitas Pertumbuhan terhadap Kemiskinan dan Laju Perubahan PDRB ADHK 33 Provinsi di Indonesia Tahun 2008-2012

\begin{tabular}{|c|c|c|c|c|c|c|c|c|c|c|}
\hline \multirow{3}{*}{ Propinsi } & \multicolumn{10}{|c|}{ Tahun } \\
\hline & \multicolumn{2}{|c|}{2008} & \multicolumn{2}{|c|}{2009} & \multicolumn{2}{|c|}{2010} & \multicolumn{2}{|c|}{2011} & \multicolumn{2}{|c|}{2012} \\
\hline & $\mathrm{IG}_{\mathrm{p}}$ & $\mathrm{G}_{\mathrm{g}}$ & $\mathrm{IG}_{\mathrm{p}}$ & $\mathrm{G}_{\mathrm{g}}$ & $\mathrm{IG}_{\mathrm{p}}$ & $G_{g}$ & $\mathrm{IG}_{\mathrm{p}}$ & $G_{g}$ & $\mathrm{IG}_{\mathrm{p}}$ & $\mathrm{G}_{\mathrm{g}}$ \\
\hline Nangroe Aceh Darussalam & $-0,07$ & $-0,05$ & $-0,08$ & $-0,06$ & 0,01 & 0,03 & 0,03 & 0,05 & 0,03 & 0,05 \\
\hline Sumatera Utara & 0,07 & 0,06 & 0,04 & 0,05 & 0,05 & 0,06 & 0,05 & 0,06 & 0,05 & 0,06 \\
\hline Sumatera Barat & 0,06 & 0,07 & 0,03 & 0,04 & 0,05 & 0,06 & 0,05 & 0,06 & 0,05 & 0,06 \\
\hline Riau & 0,03 & 0,05 & $-0,01$ & 0,03 & 0,01 & 0,04 & 0,01 & 0,05 & 0,00 & 0,03 \\
\hline Jambi & 0,00 & 0,07 & 0,04 & 0,06 & 0,05 & 0,07 & 0,06 & 0,08 & 0,05 & 0,07 \\
\hline Sumatera Selatan & 0,02 & 0,05 & 0,02 & 0,04 & 0,04 & 0,05 & 0,05 & 0,06 & 0,04 & 0,06 \\
\hline Bengkulu & 0,03 & 0,06 & 0,04 & 0,05 & 0,04 & 0,06 & 0,05 & 0,06 & 0,05 & 0,06 \\
\hline Lampung & 0,03 & 0,05 & 0,04 & 0,05 & 0,05 & 0,06 & 0,05 & 0,06 & 0,05 & 0,06 \\
\hline Kep. Bangka Belitung & 0,00 & 0,04 & 0,01 & 0,04 & 0,03 & 0,06 & 0,03 & 0,06 & 0,03 & 0,06 \\
\hline Kep.Riau & $-0,03$ & 0,06 & $-0,01$ & 0,03 & 0,03 & 0,07 & 0,01 & 0,06 & 0,03 & 0,08 \\
\hline DKI Jakarta & 0,03 & 0,06 & 0,04 & 0,05 & 0,05 & 0,06 & 0,05 & 0,07 & 0,05 & 0,06 \\
\hline Jawa Barat & 0,03 & 0,06 & 0,02 & 0,04 & 0,04 & 0,06 & 0,05 & 0,06 & 0,04 & 0,06 \\
\hline Jawa Tengah & 0,06 & 0,05 & 0,05 & 0,05 & 0,05 & 0,06 & 0,06 & 0,06 & 0,06 & 0,06 \\
\hline DI Yogyakarta & 0,06 & 0,05 & 0,03 & 0,04 & 0,04 & 0,05 & 0,04 & 0,05 & 0,04 & 0,05 \\
\hline Jawa Timur & 0,06 & 0,06 & 0,04 & 0,05 & 0,06 & 0,06 & 0,06 & 0,07 & 0,07 & 0,07 \\
\hline Banten & 0,13 & 0,20 & 0,02 & 0,05 & 0,03 & 0,06 & 0,04 & 0,06 & 0,03 & 0,06 \\
\hline Bali & 0,03 & 0,10 & 0,03 & 0,05 & 0,04 & 0,06 & 0,04 & 0,06 & 0,05 & 0,06 \\
\hline Nusa Tenggara Barat & 0,00 & 0,03 & 0,10 & 0,11 & 0,05 & $-1,38$ & $-0,04$ & 0,10 & $-0,02$ & 0,09 \\
\hline Nusa Tenggara Timur & 0,03 & 0,05 & 0,02 & 0,04 & 0,03 & $-1,41$ & 0,04 & 0,07 & 0,04 & 0,07 \\
\hline Kalimantan Barat & 0,01 & 0,04 & 0,04 & 0,05 & 0,04 & $-0,36$ & 0,05 & $-0,03$ & 0,05 & $-0,01$ \\
\hline Kalimantan Tengah & 0,01 & 0,06 & 0,04 & 0,05 & 0,05 & $-0,34$ & 0,05 & 0,05 & 0,05 & 0,05 \\
\hline Kalimantan Selatan & 0,03 & 0,06 & 0,03 & 0,05 & 0,04 & 0,04 & 0,04 & 0,06 & 0,04 & 0,06 \\
\hline Kalimantan Timur & $-0,04$ & 0,05 & $-0,01$ & 0,02 & 0,02 & $-1,73$ & 0,00 & 0,07 & 0,01 & 0,06 \\
\hline Sulawesi Utara & 0,09 & 0,10 & 0,06 & 0,08 & 0,06 & 0,58 & 0,06 & 0,06 & 0,07 & 0,06 \\
\hline Sulawesi Tengah & 0,04 & 0,09 & 0,06 & 0,07 & 0,07 & 1,92 & 0,07 & 0,04 & 0,07 & 0,04 \\
\hline Sulawesi Selatan & 0,05 & 0,07 & 0,05 & 0,06 & 0,07 & $-0,95$ & 0,06 & 0,07 & 0,07 & 0,08 \\
\hline Sulawesi Tenggara & 0,01 & 0,07 & 0,05 & 0,07 & 0,06 & 0,49 & 0,06 & 0,09 & 0,08 & 0,09 \\
\hline Gorontalo & 0,04 & 0,07 & 0,05 & 0,07 & 0,05 & 2,94 & 0,05 & 0,07 & 0,05 & 0,08 \\
\hline Sulawesi Barat & 0,03 & 0,11 & 0,03 & 0,06 & 0,09 & 1,01 & 0,07 & 0,09 & 0,06 & 0,10 \\
\hline Maluku & $-0,07$ & 0,04 & 0,03 & 0,05 & 0,04 & 0,06 & 0,03 & 0,06 & 0,05 & 0,08 \\
\hline Maluku Utara & 0,01 & 0,06 & 0,04 & 0,06 & 0,05 & 0,08 & 0,04 & 0,06 & 0,04 & 0,06 \\
\hline Papua Barat & 0,08 & 0,08 & 0,09 & 0,13 & 0,22 & 0,25 & 0,20 & 0,24 & 0,11 & 0,15 \\
\hline Papua & $-0,26$ & $-0,01$ & 0,15 & 0,20 & $-0,08$ & $-0,03$ & $-0,11$ & $-0,05$ & $-0,04$ & 0,01 \\
\hline INDONESIA & 0,04 & 0,06 & 0,03 & 0,05 & 0,04 & 0,06 & 0,05 & 0,06 & 0,05 & 0,06 \\
\hline
\end{tabular}

Sumber : Hasil Olah Koefisien Inklusifitas Provinsi, Tahun 2008-2012 (Thesis) 
Lampiran 2. Koefisien Inklusifitas Pertumbuhan terhadap Ketimpangan dan Laju Perubahan PDRB ADHK 33 provinsi di Indonesia Tahun 2008-2012

\begin{tabular}{|c|c|c|c|c|c|c|c|c|c|c|}
\hline \multirow{3}{*}{ Propinsi } & \multicolumn{10}{|c|}{ Tahun } \\
\hline & \multicolumn{2}{|c|}{2008} & \multicolumn{2}{|c|}{2009} & \multicolumn{2}{|c|}{2010} & \multicolumn{2}{|c|}{2011} & \multicolumn{2}{|c|}{2012} \\
\hline & $\mathrm{IG}_{\text {in }}$ & $\mathrm{G}_{\mathrm{g}}$ & $\mathrm{IG}_{\text {in }}$ & $G_{g}$ & $\mathrm{IG}_{\text {in }}$ & $G_{g}$ & $\mathrm{IG}_{\text {in }}$ & $G_{g}$ & $\mathrm{IG}_{\text {in }}$ & $\mathrm{G}_{\mathrm{g}}$ \\
\hline Nangroe Aceh Darussalam & NA & $-0,05$ & $-0,08$ & $-0,06$ & 0,01 & 0,03 & 0,03 & 0,05 & 0,03 & 0,05 \\
\hline Sumatera Utara & NA & 0,06 & 0,04 & 0,05 & 0,05 & 0,06 & NA & 0,06 & 0,05 & 0,06 \\
\hline Sumatera Barat & 0,06 & 0,07 & 0,03 & 0,04 & 0,05 & 0,06 & 0,05 & 0,06 & NA & 0,06 \\
\hline Riau & 0,03 & 0,05 & $-0,01$ & 0,03 & NA & 0,04 & 0,01 & 0,05 & 0,00 & 0,03 \\
\hline Jambi & 0,00 & 0,07 & 0,04 & 0,06 & 0,05 & 0,07 & 0,06 & 0,08 & 0,05 & 0,07 \\
\hline Sumatera Selatan & 0,02 & 0,05 & 0,02 & 0,04 & 0,04 & 0,05 & 0,05 & 0,06 & 0,04 & 0,06 \\
\hline Bengkulu & 0,03 & 0,06 & 0,04 & 0,05 & 0,04 & 0,06 & 0,05 & 0,06 & NA & 0,06 \\
\hline Lampung & 0,03 & 0,05 & NA & 0,05 & 0,05 & 0,06 & 0,05 & 0,06 & 0,05 & 0,06 \\
\hline Kep. Bangka Belitung & NA & 0,04 & 0,01 & 0,04 & 0,03 & 0,06 & NA & 0,06 & 0,03 & 0,06 \\
\hline Kep.Riau & NA & 0,06 & $-0,01$ & 0,03 & NA & 0,07 & 0,01 & 0,06 & 0,03 & 0,08 \\
\hline DKI Jakarta & 0,03 & 0,06 & 0,04 & 0,05 & NA & 0,06 & 0,05 & 0,07 & NA & 0,06 \\
\hline Jawa Barat & 0,03 & 0,06 & 0,02 & 0,04 & NA & 0,06 & 0,05 & 0,06 & 0,04 & 0,06 \\
\hline Jawa Tengah & 0,06 & 0,05 & 0,05 & 0,05 & 0,05 & 0,06 & 0,06 & 0,06 & 0,06 & 0,06 \\
\hline DI Yogyakarta & 0,06 & 0,05 & 0,03 & 0,04 & 0,04 & 0,05 & 0,04 & 0,05 & 0,04 & 0,05 \\
\hline Jawa Timur & 0,06 & 0,06 & NA & 0,05 & 0,06 & 0,06 & 0,06 & 0,07 & 0,07 & 0,07 \\
\hline Banten & 0,13 & 0,20 & 0,02 & 0,05 & 0,03 & 0,06 & 0,04 & 0,06 & 0,03 & 0,06 \\
\hline$\overline{\text { Bali }}$ & 0,03 & 0,10 & 0,03 & 0,05 & 0,04 & 0,06 & 0,04 & 0,06 & 0,05 & 0,06 \\
\hline Nusa Tenggara Barat & NA & 0,03 & 0,10 & 0,11 & 0,05 & $-1,38$ & $-0,04$ & 0,10 & $-0,02$ & 0,09 \\
\hline Nusa Tenggara Timur & 0,03 & 0,05 & 0,02 & 0,04 & 0,03 & $-1,41$ & 0,04 & 0,07 & NA & 0,07 \\
\hline Kalimantan Barat & NA & 0,04 & 0,04 & 0,05 & 0,04 & $-0,36$ & 0,05 & $-0,03$ & NA & $-0,01$ \\
\hline Kalimantan Tengah & 0,01 & 0,06 & NA & 0,05 & 0,05 & $-0,34$ & 0,05 & 0,05 & 0,05 & 0,05 \\
\hline Kalimantan Selatan & 0,03 & 0,06 & 0,03 & 0,05 & 0,04 & 0,04 & NA & 0,06 & 0,04 & 0,06 \\
\hline Kalimantan Timur & $-0,04$ & 0,05 & $-0,01$ & 0,02 & 0,02 & $-1,73$ & 0,00 & 0,07 & 0,01 & 0,06 \\
\hline Sulawesi Utara & 0,09 & 0,10 & 0,06 & 0,08 & 0,06 & 0,58 & 0,06 & 0,06 & 0,07 & 0,06 \\
\hline Sulawesi Tengah & 0,04 & 0,09 & 0,06 & 0,07 & 0,07 & 1,92 & 0,07 & 0,04 & 0,07 & 0,04 \\
\hline Sulawesi Selatan & 0,05 & 0,07 & 0,05 & 0,06 & 0,07 & $-0,95$ & 0,06 & 0,07 & 0,07 & 0,08 \\
\hline Sulawesi Tenggara & 0,01 & 0,07 & 0,05 & 0,07 & 0,06 & 0,49 & 0,06 & 0,09 & 0,08 & 0,09 \\
\hline Gorontalo & 0,04 & 0,07 & 0,05 & 0,07 & 0,05 & 2,94 & 0,05 & 0,07 & 0,05 & 0,08 \\
\hline Sulawesi Barat & NA & 0,11 & 0,03 & 0,06 & 0,09 & 1,01 & 0,07 & 0,09 & 0,06 & 0,10 \\
\hline Maluku & $-0,07$ & 0,04 & NA & 0,05 & 0,04 & 0,06 & 0,03 & 0,06 & 0,05 & 0,08 \\
\hline Maluku Utara & NA & 0,06 & NA & 0,06 & 0,05 & 0,08 & 0,04 & 0,06 & 0,04 & 0,06 \\
\hline Papua Barat & 0,08 & 0,08 & 0,09 & 0,13 & 0,22 & 0,25 & 0,20 & 0,24 & 0,11 & 0,15 \\
\hline Papua & $-0,26$ & $-0,01$ & 0,15 & 0,20 & $-0,08$ & $-0,03$ & $-0,11$ & $-0,05$ & $-0,04$ & 0,01 \\
\hline INDONESIA & 0,04 & 0,06 & 0,03 & 0,05 & 0,04 & 0,06 & 0,05 & 0,06 & NA & 0,06 \\
\hline
\end{tabular}

Sumber : Hasil Olah Koefisien Inklusifitas Provinsi, Tahun 2008-2012 (Thesis) 
Lampiran 3. Koefisien Inklusifitas Pertumbuhan terhadap Penyerapan Tenaga Kerja dan Laju Perubahan PDRB ADHK 33 provinsi di Indonesia Tahun 2008-2012

\begin{tabular}{|c|c|c|c|c|c|c|c|c|c|c|}
\hline \multirow{3}{*}{ Propinsi } & \multicolumn{10}{|c|}{ Tahun } \\
\hline & \multicolumn{2}{|c|}{2008} & \multicolumn{2}{|c|}{2009} & \multicolumn{2}{|c|}{2010} & \multicolumn{2}{|c|}{2011} & \multicolumn{2}{|c|}{2012} \\
\hline & $\mathrm{IG}_{\mathrm{em}}$ & $\mathrm{G}_{\mathrm{g}}$ & $\mathrm{IG}_{\mathrm{em}}$ & $\mathrm{G}_{\mathrm{g}}$ & $\mathrm{IG}_{\mathrm{em}}$ & $\mathrm{G}_{\mathrm{g}}$ & $\mathrm{IG}_{\mathrm{em}}$ & $\mathrm{G}_{\mathrm{g}}$ & $\mathrm{IG}_{\mathrm{em}}$ & $\mathrm{G}_{\mathrm{g}}$ \\
\hline Nangroe Aceh Darussalam & 0,03 & $-0,05$ & 0,06 & $-0,06$ & 0,02 & 0,03 & 0,03 & 0,05 & 0,04 & 0,05 \\
\hline Sumatera Utara & 0,08 & 0,06 & 0,03 & 0,05 & 0,05 & 0,06 & $-0,05$ & 0,06 & 0,04 & 0,06 \\
\hline Sumatera Barat & 0,01 & 0,07 & 0,02 & 0,04 & 0,01 & 0,06 & 0,01 & 0,06 & 0,06 & 0,06 \\
\hline Riau & 0,06 & 0,05 & 0,01 & 0,03 & 0,05 & 0,04 & 0,07 & 0,05 & 0,02 & 0,03 \\
\hline Jambi & 0,05 & 0,07 & 0,03 & 0,06 & 0,15 & 0,07 & $-0,03$ & 0,08 & 0,04 & 0,07 \\
\hline Sumatera Selatan & 0,03 & 0,05 & 0,00 & 0,04 & 0,06 & 0,05 & 0,03 & 0,06 & 0,04 & 0,06 \\
\hline Bengkulu & 0,01 & 0,06 & 0,02 & 0,05 & 0,03 & 0,06 & 0,05 & 0,06 & 0,02 & 0,06 \\
\hline Lampung & 0,01 & 0,05 & 0,02 & 0,05 & 0,09 & 0,06 & $-0,07$ & 0,06 & 0,06 & 0,06 \\
\hline Kep. Bangka Belitung & 0,03 & 0,04 & 0,03 & 0,04 & 0,14 & 0,06 & $-0,01$ & 0,06 & 0,01 & 0,06 \\
\hline Kep.Riau & 0,12 & 0,06 & 0,02 & 0,03 & 0,19 & 0,07 & 0,03 & 0,06 & 0,05 & 0,08 \\
\hline DKI Jakarta & 0,08 & 0,06 & $-0,02$ & 0,05 & 0,12 & 0,06 & $-0,02$ & 0,07 & 0,03 & 0,06 \\
\hline Jawa Barat & 0,03 & 0,06 & 0,01 & 0,04 & 0,00 & 0,06 & 0,02 & 0,06 & 0,04 & 0,06 \\
\hline Jawa Tengah & $-0,06$ & 0,05 & 0,02 & 0,05 & $-0,01$ & 0,06 & 0,00 & 0,06 & 0,01 & 0,06 \\
\hline DI Yogyakarta & 0,06 & 0,05 & 0,01 & 0,04 & $-0,07$ & 0,05 & 0,00 & 0,05 & 0,03 & 0,05 \\
\hline Jawa Timur & 0,00 & 0,06 & 0,01 & 0,05 & $-0,04$ & 0,06 & 0,01 & 0,07 & 0,00 & 0,07 \\
\hline Banten & 0,07 & 0,20 & 0,01 & 0,05 & 0,20 & 0,06 & $-0,02$ & 0,06 & 0,04 & 0,06 \\
\hline Bali & 0,02 & 0,10 & 0,01 & 0,05 & 0,06 & 0,06 & 0,00 & 0,06 & 0,02 & 0,06 \\
\hline Nusa Tenggara Barat & $-0,03$ & 0,03 & 0,03 & 0,11 & 0,07 & $-1,38$ & $-0,08$ & 0,10 & 0,05 & 0,09 \\
\hline Nusa Tenggara Timur & 0,04 & 0,05 & 0,04 & 0,04 & $-0,05$ & $-1,41$ & 0,01 & 0,07 & 0,05 & 0,07 \\
\hline Kalimantan Barat & 0,01 & 0,04 & 0,02 & 0,05 & 0,00 & $-0,36$ & 0,02 & $-0,03$ & 0,01 & $-0,01$ \\
\hline Kalimantan Tengah & 0,01 & 0,06 & 0,02 & 0,05 & 0,02 & $-0,34$ & 0,06 & 0,05 & 0,02 & 0,05 \\
\hline Kalimantan Selatan & 0,03 & 0,06 & 0,02 & 0,05 & 0,01 & 0,04 & 0,05 & 0,06 & $-0,02$ & 0,06 \\
\hline Kalimantan Timur & 0,13 & 0,05 & 0,03 & 0,02 & 0,12 & $-1,73$ & 0,07 & 0,07 & 0,04 & 0,06 \\
\hline Sulawesi Utara & $-0,02$ & 0,10 & 0,03 & 0,08 & $-0,01$ & 0,58 & 0,04 & 0,06 & 0,03 & 0,06 \\
\hline Sulawesi Tengah & 0,01 & 0,09 & 0,02 & 0,07 & 0,00 & 1,92 & 0,07 & 0,04 & 0,03 & 0,04 \\
\hline Sulawesi Selatan & 0,04 & 0,07 & 0,03 & 0,06 & 0,01 & $-0,95$ & 0,01 & 0,07 & 0,01 & 0,08 \\
\hline Sulawesi Tenggara & 0,02 & 0,07 & 0,02 & 0,07 & 0,05 & 0,49 & 0,01 & 0,09 & 0,03 & 0,09 \\
\hline Gorontalo & 0,09 & 0,07 & 0,04 & 0,07 & 0,02 & 2,94 & 0,02 & 0,07 & 0,01 & 0,08 \\
\hline Sulawesi Barat & 0,05 & 0,11 & 0,03 & 0,06 & 0,04 & 1,01 & 0,04 & 0,09 & 0,02 & 0,10 \\
\hline Maluku & 0,01 & 0,04 & 0,06 & 0,05 & 0,09 & 0,06 & 0,07 & 0,06 & $-0,02$ & 0,08 \\
\hline Maluku Utara & 0,06 & 0,06 & 0,00 & 0,06 & 0,04 & 0,08 & 0,06 & 0,06 & 0,02 & 0,06 \\
\hline Papua Barat & 0,15 & 0,08 & 0,03 & 0,13 & $-0,03$ & 0,25 & 0,08 & 0,24 & 0,04 & 0,15 \\
\hline Papua & 0,08 & $-0,01$ & 0,05 & 0,20 & 0,29 & $-0,03$ & 0,02 & $-0,05$ & 0,04 & 0,01 \\
\hline INDONESIA & 0,02 & 0,06 & 0,02 & 0,05 & 0,02 & 0,06 & 0,01 & 0,06 & 0,03 & 0,06 \\
\hline
\end{tabular}

Sumber : Hasil Olah Koefisien Inklusifitas Provinsi, Tahun 2008-2012 (Thesis) 